\title{
Replacement of Fish Meal by Black Soldier Fly (Hermetia illucens) Larvae Meal: Effects on Growth, Haematology, and Skin Mucus Immunity of Nile Tilapia, Oreochromis niloticus
}

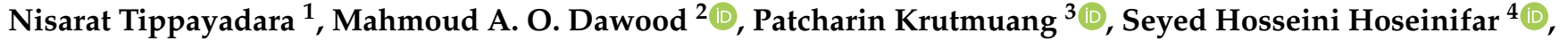 \\ Hien Van Doan ${ }^{5, *}$ (D) and Marina Paolucci ${ }^{6}$ (D) \\ 1 Faculty of interdisciplinary Studies, Khon Kaen University, Nong Khai 43000, Thailand; nisati@kku.ac.th \\ 2 Department of Animal Production, Faculty of Agriculture, Kafrelsheikh University, \\ Kafrelsheikh 33516, Egypt; mahmouddawood55@gmail.com \\ 3 Department of Entomology and Plant Pathology, Faculty of Agriculture, Chiang Mai University, \\ Chiang Mai 50200, Thailand; patcharin.k@cmu.ac.th \\ 4 Department of Fisheries Gorgan, University of Agricultural Sciences and Natural Resources, Gorgan, Iran; \\ hossein.hoseinifar@gmail.com \\ 5 Department of Animal and Aquatic Sciences, Faculty of Agriculture, Chiang Mai University, \\ Chiang Mai 50200, Thailand \\ 6 Department of Sciences and Technologies, University of Sannio, 82100 Benevento, Italy; \\ paolucci@unisannio.it \\ * Correspondence: hien.d@cmu.ac.th
}

\section{check for}

updates

Citation: Tippayadara, N.; Dawood, M.A.O.; Krutmuang, P.; Hoseinifar,

S.H.; Doan, H.V.; Paolucci, M.

Replacement of Fish Meal by Black

Soldier Fly (Hermetia illucens) Larvae

Meal: Effects on Growth,

Haematology, and Skin Mucus

Immunity of Nile Tilapia, Oreochromis

niloticus. Animals 2021, 11, 193.

https://doi.org/10.3390/ani11010193

Received: 8 December 2020

Accepted: 11 January 2021

Published: 15 January 2021

Publisher's Note: MDPI stays neutral with regard to jurisdictional clai$\mathrm{ms}$ in published maps and institutional affiliations.

Copyright: (C) 2021 by the authors. Licensee MDPI, Basel, Switzerland. This article is an open access article distributed under the terms and conditions of the Creative Commons Attribution (CC BY) license (https:// creativecommons.org/licenses/by/ $4.0 /)$.
Simple Summary: Fish meal (FM) is the primary ingredient of the farmed fish's diet. However, the decline in wild fish catches, and the growing demand for aquaculture feed have resulted in a dramatic reduction of FM supply. Thus, it is essential to seek for alternatives, such as insect meal (IM), to support sustainable aquafeed production. Among insects, the black soldier fly larvae are promising because they are rich in essential amino acids, minerals, and vitamins. Therefore, the present study was performed to assess the effects of IM as a partial or total replacement of FM on the growth and hematological parameters and skin mucus immunity of Nile tilapia. Growth and feed utilization efficiency indices, feed intake, survival rates, and hematological parameters were not significantly different between FM and IM fed fish, while the mucosal immune response was improved in IM fed fish. In conclusion, these results show that IM can be used to substitute FM in the Nile tilapia diet. These findings can be used to develop alternative aquafeed for sustainable aquaculture.

Abstract: Fish meal (FM) is no longer a sustainable source for the increasing aquaculture industry. Animal proteins from insects may be used as a FM alternative source as long as they do not create adverse effects in fish. Black soldier fly larvae meal (BSFLM) was tested in a 12-week experiment on Nile tilapia (Oreochromis niloticus). Four hundred and twenty (14.77 $\pm 2.09 \mathrm{~g})$ fish were divided into seven groups and were fed seven diets: control (0\% BSFLM-100\% FM), and FM replaced by BSFLM at rates of $10 \%, 20 \%, 40 \%, 60 \%, 80 \%$ and $100 \%$. Growth indexes, feed utilization efficiency indices, feed intake, and survival rate were not significantly different $(p>0.05)$ between FM and BSFLM fed fish. Values of red blood cell, white blood cells, hemoglobin, hematocrit, mean corpuscular volume and hemoglobin, mean corpuscular hemoglobin concentration, red blood cell distribution width, and platelet values were not affected by BSFLM. Skin, mucus lysozyme, and peroxidase activities were improved in BSFLM fed fish. BSFLM can be used as a substitution for FM in the Nile tilapia (O. niloticus) diet at up to a $100 \%$ rate with no adverse effects.

Keywords: sustainable aquaculture; fish meal; black soldier fly larvae meal; Hermetia illucens; Nile tilapia; Oreochromis niloticus; growth performance; haematological parameters; skin mucus immunity 


\section{Introduction}

The aquaculture sector increases by around $5.8 \%$ yearly because of rapid expansion and intensification across the industry [1]. Fishmeal (FM) has been used as the primary protein ingredient in aquaculture for decades because of its balanced essential amino acids, easy digestibility, and palatability, crucial attributes to enhance nutrient digestion and absorption [2]. Nevertheless, the gradual decline in wild fish catches, and the growing demand for aquaculture feed resulted in a dramatically reduced supply of FM and the elevation of diet prices [3,4]. FM is believed to no longer be capable of supporting the development of the aquaculture industry in the coming years $[5,6]$. This raises the need to seek better alternatives to FM for sustainable aquafeed production [7].

Protein sources of animal origins, such as insect meal (IM), can be used as alternative sources for fish meal in aqua-feed [8-10]. In recent years, interest in the study of IM in fish farming as a feasible alternative to feed has risen dramatically [11,12]. IM is a good source of protein, minerals, and vitamins, similar to FM [13]. It is also rich in essential amino acids, especially lysine, methionine, and leucine, containing no anti-nutritional elements $[14,15]$. Among insects, the black soldier fly larvae (BSFL) are particularly promising because of their ability to turn food waste into premium protein, and as such mass production has increased over recent years $[7,8]$. The BSFL contain about $30-58 \%$ protein and $10-30 \%$ lipids and essential amino acids, similar to FM [16-18]. They also contain many macroand micro- minerals, as well as valuable vitamins [19].

The partial or total replacement of dietary FM with BSFL has been successfully demonstrated in various fish species, such as: rainbow trout, Oncorhynchus mykiss [20]; Japanese seabass, Lateolabrax japonicus [21]; Atlantic salmon, Salmo salar [8,10]; European sea bass, Dicentrarchus labrax [7]; hybrid tilapia (Nile $\times$ Mozambique, Oreochromis niloticus $\times$ O. mozambique) [22]; marron, Cherax cainii [23]; and rice field eel, Monopterus albus [24]. However, as far as we know, there is limited information regarding the effects of black soldier fly larvae meal (BSFLM) on the growth, hematology, and skin mucus of Nile tilapia, which occupies the second highest position in the world in terms of production due to its high demand, rapid growth, and fair prices [25,26]. Therefore, the present study was performed to assess the effects of using BSFLM as a partial or total replacement for dietary FM on the growth, hematology, and skin mucus immunity of Nile tilapia, O. niloticus.

\section{Materials and Methods}

\subsection{Black Soldier Fly Larvae Meal (BSFLM) Preparation}

Black soldier fly larvae (Hermetia illucens) were provided by Prof. Dr. Patcharin Krutmuang, Department of Entomology and Plant Pathology, Faculty of Agriculture, Chiang Mai University, Chiang Mai 50200, Thailand. They were dried in a hot air oven at $50{ }^{\circ} \mathrm{C}$ for $24 \mathrm{~h}$. They were then ground into a fine powder and kept at $4{ }^{\circ} \mathrm{C}$ for further use.

\subsection{Experimental Diets}

The basal diet, which has been demonstrated to be suitable for Nile tilapia [27] was prepared with the substitution of FM with BSFLM: 0 (Diet 1-control), 10\% (Diet 2), $20 \%$ (Diet 3), Diet $4(40 \%)$, Diet 5 (60\%), Diet $6(80)$, and Diet 7 (100\%). Ingredients and proximate composition of the basal diet and proximate composition of BSFLM are given in Tables 1 and 2, respectively. Powdered feed obtained from Baan Pramong Company Limited, Bangrabow, Ban Sang, Prachinburi, 25150, Thailand was completely mixed into the manufacturing of feed pellets, and soybean oil and water were added to make a stiff dough. It was then moved to form the pellets through an extruder at a temperature of $100{ }^{\circ} \mathrm{C}$. The wet pellets (size $2 \mathrm{~mm}$ ) were then collected and dehydrated in a $50{ }^{\circ} \mathrm{C}$ hot air oven to achieve a moisture content of three percent, then placed in plastic bags and stored at $4{ }^{\circ} \mathrm{C}$. The composition of the diets was analyzed following the method of AOAC-Association of Official Analytical Chemists [28]. 
Table 1. Ingredients and proximate composition of the experimental diets.

\begin{tabular}{|c|c|c|c|c|c|c|c|}
\hline \multirow{2}{*}{ Ingredients (g/kg DM) } & \multicolumn{7}{|c|}{ Diets } \\
\hline & Diet 1 & Diet 2 & Diet 3 & Diet 4 & Diet 5 & Diet 6 & Diet 7 \\
\hline Fish meal (FM) & 100 & 90 & 80 & 60 & 40 & 20 & 0 \\
\hline BSFLM $^{1}$ & 0 & 10 & 20 & 40 & 60 & 80 & 100 \\
\hline Corn meal & 200 & 200 & 200 & 200 & 200 & 200 & 200 \\
\hline Soybean meal & 450 & 440 & 435 & 415 & 400 & 380 & 365 \\
\hline Wheat flour & 60 & 60 & 60 & 60 & 60 & 60 & 60 \\
\hline Rice bran & 150 & 160 & 165 & 185 & 200 & 220 & 235 \\
\hline Cellulose & 20 & 20 & 20 & 20 & 20 & 20 & 20 \\
\hline Soybean oil & 5 & 5 & 5 & 5 & 5 & 5 & 5 \\
\hline Premix $^{2}$ & 10 & 10 & 10 & 10 & 10 & 10 & 10 \\
\hline Vitamin $C^{3}$ & 5 & 5 & 5 & 5 & 5 & 5 & 5 \\
\hline \multicolumn{8}{|c|}{ Proximate composition } \\
\hline Dry matter (\%) & 97.15 & 97.05 & 96.95 & 96.95 & 97.10 & 96.85 & 96.95 \\
\hline Crude protein $(\%)$ & 30.21 & 29.98 & 29.90 & 29.83 & 29.79 & 29.18 & 28.81 \\
\hline Crude fiber (\%) & 3.10 & 2.90 & 2.43 & 3.01 & 3.14 & 3.22 & 2.52 \\
\hline Crude lipid (\%) & 4.78 & 4.79 & 4.78 & 4.83 & 4.75 & 4.85 & 4.73 \\
\hline Ash (\%) & 6.92 & 6.62 & 6.17 & 6.16 & 5.65 & 5.39 & 4.95 \\
\hline $\mathrm{Ca}(\%)$ & 0.98 & 0.87 & 0.87 & 0.75 & 0.56 & 0.39 & 0.25 \\
\hline $\mathrm{P}(\%)$ & 1.00 & 1.03 & 0.97 & 1.00 & 0.90 & 0.92 & 0.93 \\
\hline Gross energy (kJ /g) & 17.37 & 17.37 & 17.29 & 17.37 & 17.37 & 17.29 & 17.37 \\
\hline
\end{tabular}

${ }^{1}$ BSFLM = Black soldier fly larvae meal. ${ }^{2}$ Vitamin and trace mineral mix supplemented as follows (IU kg ${ }^{-1} \mathrm{or} \mathrm{g} \mathrm{kg}^{-1}$ diet): retinyl acetate 1,085,000 IU; cholecalciferol 217,000 IU; D, L-a-tocopherol acetate $0.5 \mathrm{~g}$; thiamin nitrate $0.5 \mathrm{~g}$; pyridoxine hydrochloride $0.5 \mathrm{~g}$; niacin $3 \mathrm{~g}$; folic $0.05 \mathrm{~g}$; cyanocobalamin $10 \mathrm{~g}$; Ca pantothenate $1 \mathrm{~g} \mathrm{~kg}^{-1}$; inositol $0.5 \mathrm{~g}$; zinc $1 \mathrm{~g}$; copper $0.25 \mathrm{~g}$; manganese $1.32 \mathrm{~g}$; iodine $0.05 \mathrm{~g}$; sodium 7.85 g. ${ }^{3}$ Vitamin C $98 \% 5$ g.

Table 2. Composition of BSFLM.

\begin{tabular}{cc}
\hline Composition & Amount \\
\hline Energy (Kcal) & 461 \\
\hline Water $(\%)$ & 23.33 \\
\hline Protein $(\%)$ & 26.12 \\
\hline Fat $(\%)$ & 36.47 \\
\hline Carbohydrate $(\%)$ & 7.24 \\
\hline Dietary fiber $(\%)$ & 3.62 \\
\hline Ash $(\%)$ & 6.84 \\
\hline Lauric acid $(\%)$ & 17.25 \\
\hline Total vitamin A $(\mu \mathrm{g} / \mathrm{g})$ & 0 \\
\hline Vitamin B1 $(\mathrm{mg} / \mathrm{g})$ & 0.26 \\
\hline Omega-3 $(\mathrm{mg} / \mathrm{g})$ & 244.71 \\
\hline Omega-6 $(\mathrm{mg} / \mathrm{g})$ & 2835.37 \\
\hline Omega-9 $(\mathrm{mg} / \mathrm{g})$ & 4100.19 \\
\hline
\end{tabular}

\subsection{Experimental Procedure}

Chitralada 3 Nile tilapia (O. niloticus) fingerlings were purchased from Inland Aquaculture Research and Development Division, Department of Fisheries, Thailand. Fish were fed a commercial feed from Charoen Pokphand Foods Public Company Limited (CP, 9950) for 4 weeks and a basal diet for 15 days. Afterward, 420 fish $\left(14.77 \pm 2.09 \mathrm{~g}\right.$ fish $\left.^{-1}\right)$ were later captured and distributed into 21 glass tanks (volume $100 \mathrm{~L} \mathrm{tank}^{-1}$ ) at a density of 20 fish/tank. Each aquarium was supplied with continuous aeration via compressed air. Fish were divided into 7 treatments in triplicates and fed on tested diets up to apparent 
satiation at 9:00 and 16:00 h for 12 weeks. The light was maintained at a 12:12 h light:dark cycle with natural light. To maintain clear and healthy water throughout the experimental period, three-quarters of the aquarium's water was siphoned daily to remove feces and uneaten food and was replaced with clean well-aerated water from a storage tank.

\subsection{Water Quality Measurement}

Water quality assessment was conducted every two weeks. Water temperature and dissolved oxygen were measured using a YSI Model 52 meter. $\mathrm{pH}$ and NH4+ + NH3 were measured using an IQ scientific meter and Phenate-hypochlorite following the method of [29]. The TSD and conductivity were measured using HI 98311 (Hanna Instruments, Bangkok, Thailand). The temperature $\left(0{ }^{\circ} \mathrm{C}\right)$, conductivity $(\mu \mathrm{S} / \mathrm{cm}), \mathrm{TDS}(\mathrm{mg} / \mathrm{L})$, dissolved oxygen $(\mathrm{mg} / \mathrm{L}), \mathrm{pH}$, and total ammonia $(\mathrm{mg} / \mathrm{L})$ were $28.93 \pm 1.60,341.93 \pm 31.07$, $135.25 \pm 21.76,5.41 \pm 0.23,7.30 \pm 0.17$, and $0.09 \pm 0.07$, respectively.

\subsection{Sample Collections}

\subsubsection{Blood Collection and Hematological Parameters}

Fish were fasted for $24 \mathrm{~h}$ prior to the blood collection and anesthetized using clove oil $\left(5 \mathrm{~mL} \mathrm{~L}^{-1}\right)$. Then, one $\mathrm{mL}$ of blood was taken from the fish's caudal vein (15 fish per treatment). The anticoagulant was heparin sodium. The blood with the anticoagulant was immediately transferred into a 1.8 Eppendorf tube and stored at $4{ }^{\circ} \mathrm{C}$ for further analysis. The red blood cell (RBC), hemoglobin ( $\mathrm{Hb})$, hematocrit (HCT), mean corpuscular volume $(\mathrm{MCV})$, mean corpuscular hemoglobin $(\mathrm{MCH})$, mean corpuscular hemoglobin concentration (MCHC), red blood cell distribution width (RDW-CV), and platelet (PLT) values were measured via a blood cell analyzer (Sysmex/XN-1000 S/N 19393, Meditop, Soi Lat Phrao, Thailand). The measurement of RBC and white blood cell (WBC) counts were performed as described in [30], while differential counts of lymphocytes, monocytes, and neutrophils were detected by smears stained with Wright Giemsa.

\subsubsection{Skin Mucus Preparation}

Skin mucus was collected from 3 fish and pooled as reported in [31]. Briefly, the anesthetized fish with clove oil $\left(5 \mathrm{~mL} \mathrm{~L}^{-1}\right.$ of water) were put in a polyethene bag containing $10 \mathrm{~mL}$ of $50 \mathrm{mM} \mathrm{NaCl}$. Fish were gently rubbed inside the bag for two minutes. Afterward, the solution was immediately released into a $15 \mathrm{~mL}$ sterile tube and centrifuged at $1500 \times g$ at $4{ }^{\circ} \mathrm{C}$ for ten minutes (5810R Eppendorf, Engelsdorf, Germany). Then, $500 \mu \mathrm{L}$ of supernatant were gathered and kept at $-80{ }^{\circ} \mathrm{C}$ for further analysis.

\subsection{Growth Parameter Calculations}

At every 2 weeks interval, all fish were fasted for $24 \mathrm{~h}$, and then growth parameters and survival rates were determined using the following formulae: Daily weight gain $(\mathrm{DWG})=($ mean final weigh $-\mathrm{tcmean}$ initial weight $) \div \mathrm{t}($ days $) ;$ Weight gain $(\mathrm{WG})=($ mean final weight - mean initial weight); Specific growth rate $(\mathrm{SGR} \% /$ day $)=100 \times(\operatorname{lnWt}$ $-\ln W o) \div \mathrm{t}$ (days); Relative growth rate $(\mathrm{RGR} \%)=$ [Wf (final weight) $-\mathrm{Wi}$ (initial weight)] $/ \mathrm{Wf} \times 100$; Food conversion ratio $(\mathrm{FCR})=$ Total amount of the feed consumed $(\mathrm{g}) /$ Wet weight gain; Feed efficiency $(\mathrm{FE} \%)=(1 / \mathrm{FCR}) \times 100$, and Survival: $(\mathrm{SR} \%)=100$ $(\mathrm{Nf} \div \mathrm{Ni})$ with $\mathrm{Nf}$ and $\mathrm{Ni}$ : final and initial number of fish.

\subsection{Fish Morphometric Indices}

After exsanguination, 15 fish per treatment were dissected for hepatopancreas and viscera collection. After that, they were placed in saline solution $(0.86 \%)$ and stored at $-20{ }^{\circ} \mathrm{C}$. The fish's morphometric indices were calculated as the following equations: Condition factor $(\mathrm{CF})=100 \times \mathrm{BW}$ in $\mathrm{g} /\left(\mathrm{TL}\right.$ in $\left.\mathrm{cm}^{3}\right)$; Hepatosomatic index $(\mathrm{HSI})=100 \times($ liver weight (g)/whole fish weight $(\mathrm{g}))$; Viscerosomatic index $(\mathrm{VSI})=100 \times($ viscera weight $(\mathrm{g}) /$ whole fish weight $(\mathrm{g})$ ). 


\subsection{Digestible Efficiency Measurement}

Apparent digestibility coefficients were determined following the method reported in [32] with the use of $0.5 \%$ chromic oxide as a marker. Fish's feces in each tank were collected and stored at $-20{ }^{\circ} \mathrm{C}$, and then oven-dried at $50{ }^{\circ} \mathrm{C}$ for $48 \mathrm{~h}$. The dried feces were used for analyzing chromic oxide and nutrients, according to the method described in [33]. Apparent digestibility coefficients (ADC) were measured by the following equation ADCdiet $=\left[1-\left(\right.\right.$ dietary $\mathrm{Cr}_{2} \mathrm{O}_{3}$ level $\times$ feces nutrient or energy level: feces $\mathrm{Cr}_{2} \mathrm{O}_{3}$ level $\times$ dietary nutrient or energy level) $] \times 100$.

\subsection{Mucosal Immune Responses}

\subsubsection{Skin Mucus Lysozyme Assay}

Skin mucus lysozyme was determined using the method reported in [34] with slight modifications, as mentioned in [35]. Briefly, $100 \mu \mathrm{L}$ of skin mucus from each fish were loaded into 96 well-plates, in triplicate. Micrococcus lysodeikticus $\left(100 \mu \mathrm{L}, 0.3 \mathrm{mg} \mathrm{mL}^{-1}\right.$ in $0.1 \mathrm{M}$ citrate phosphate buffer, $\mathrm{pH}$ 5.8; Sigma-Aldrich, Co Ltd, Bangkok, Thailand ) solution was loaded into each well and gently mixed. The change in turbidity was recorded every $30 \mathrm{~s}$ for $10 \mathrm{~min}$ at $540 \mathrm{~nm}, 25^{\circ} \mathrm{C}$ using a microplate reader. The sample's equivalent unit of activity was determined and compared with the standard, and expressed as $\mu \mathrm{g} \mathrm{mL}{ }^{-1}$ serum.

\subsubsection{Skin Mucus Peroxidase Assay}

Peroxidase activity was performed using the protocol reported in [36] with modification as mentioned in [35]. Briefly, $5 \mu \mathrm{L}$ of skin mucus from each fish were loaded into 96 flat-bottomed well-plates in triplicate. Then, $45 \mu \mathrm{L}$ of Hank's Balanced Salt Solution (without $\mathrm{Ca}^{+2}$ or $\mathrm{Mg}^{+2}$ ) and $100 \mu \mathrm{L}$ of solution (contains $40 \mathrm{~mL}$ of distilled water $+10 \mu \mathrm{L}$ of $\mathrm{H}_{2} \mathrm{O}_{2}, 30 \%$; Sigma Aldrich + one pill of 3,3',5,5'-tetramethylbenzidine, TMB; Sigma Aldrich) were added into each well. Once the reaction color turned blue (30-60 s), $50 \mu \mathrm{L}$ of $2 \mathrm{M}$ $\mathrm{H}_{2} \mathrm{SO}_{4}$ were added to each well. The optical density was read at $450 \mathrm{~nm}$ by a microplate reader (Synergy H1, BioTek, Winooski, VT, USA, USA). Samples not containing serum or skin mucus were considered to be blanks. A single unit was defined as the amount which produced an absorbance change, expressed as units $(\mathrm{U}) \mathrm{mL}^{-1}$ of serum or mucus.

\subsection{Statistical Analysis}

One-way variance analysis (ANOVA) and Duncan's Multiple Range Test) using SAS software, 2003 were applied for data analysis after checking the normality of the data by the Kolmogorov-Smirnov test. Various mean values $(p<0.05)$ and other measurements are shown as mean \pm SD. The optimum BSFLM level was determined using quadratic and linear regression analyses [37].

\section{Results}

\subsection{Growth Performance}

Growth and feed utilization parameters are displayed in Tables 3 and 4. The results indicate that the highest growth parameters were observed in fish Diets 3 and 4 (Table 3).

However, no significant differences were recorded between black soldier fly larvae meal (BSFLM) and the control diets. No differences in appetite were detected between fish fed on modified diets and controls. Moreover, no significant differences in total feed intake, and rate of fish intake, fish conversion ratio, feed efficiency, and total digestibility were displayed between the control and BSFLM substitution fed fish (Table 4). In con trast, a significant increase in apparent protein digestibility coefficient was observed in fish fed BSFLM compared to the control, and the highest value was observed in fish fed Diet 7 (Table 4). 
Table 3. Growth parameters (mean \pm standard deviation, SD) after 12 weeks of feeding with control $(0 \%$ BSFLM and $100 \%$ FM, and FM replaced at $10 \%, 20 \%, 40 \%, 60 \%, 80 \%$, and $100 \%$ of the BSFLM.

\begin{tabular}{ccccccccc}
\hline Diets & IBW & FBW & DWG & WG & SGR & RGR & HPA & SR \\
\hline 1 & $14.62 \pm 1.90$ & $44.04 \pm 3.52$ & $0.35 \pm 0.03$ & $29.42 \pm 2.19$ & $1.32 \pm 0.10$ & $66.85 \pm 2.67$ & $0.88 \pm 0.07$ & 100 \\
2 & $15.31 \pm 2.24$ & $45.25 \pm 5.40$ & $0.36 \pm 0.04$ & $29.95 \pm 3.17$ & $1.29 \pm 0.03$ & $66.25 \pm 0.95$ & $0.91 \pm 0.11$ & 100 \\
3 & $14.72 \pm 3.36$ & $46.35 \pm 0.71$ & $0.38 \pm 0.04$ & $31.63 \pm 3.02$ & $1.39 \pm 0.26$ & $68.28 \pm 7.02$ & $0.93 \pm 0.01$ & 100 \\
4 & $14.66 \pm 2.82$ & $47.52 \pm 3.86$ & $0.39 \pm 0.02$ & $32.86 \pm 1.51$ & $1.41 \pm 0.15$ & $69.32 \pm 3.75$ & $0.95 \pm 0.08$ & 100 \\
5 & $14.91 \pm 2.06$ & $47.38 \pm 4.22$ & $0.39 \pm 0.03$ & $32.47 \pm 2.87$ & $1.38 \pm 0.10$ & $68.57 \pm 2.66$ & $0.95 \pm 0.08$ & 100 \\
6 & $14.67 \pm 2.61$ & $44.58 \pm 4.40$ & $0.36 \pm 0.04$ & $29.91 \pm 3.02$ & $1.33 \pm 0.16$ & $67.16 \pm 4.31$ & $0.89 \pm 0.09$ & 100 \\
7 & $14.51 \pm 2.06$ & $43.02 \pm 3.15$ & $0.34 \pm 0.04$ & $28.50 \pm 3.37$ & $1.30 \pm 0.17$ & $66.19 \pm 4.70$ & $0.86 \pm 0.06$ & 100 \\
$p$-value & 1.000 & 0.734 & 0.442 & 0.442 & 0.937 & 0.946 & 0.734 & 100 \\
Means overall & $14.77 \pm 2.09$ & $45.45 \pm 3.61$ & $0.37 \pm 0.03$ & $30.68 \pm 2.82$ & $1.35 \pm 0.14$ & $67.52 \pm 3.64$ & $0.91 \pm 0.07$ & 100 \\
\hline
\end{tabular}

IBW $(\mathrm{g})=$ Initial body weight; FBW (g) = Final body weight; DWG $(\mathrm{g})$ = Daily weight gain ( $\mathrm{g}$ per day); WG $(\mathrm{g})$ = Weight gain; SGR $(\% /$ day $)=$ Specific growth rate $(\%$ per day $) ;$ RGR $(\%)=$ Relative growth rate; HPA = Harvest $(\mathrm{kg}$ per aquaria $) ;$ SR $(\%)=$ Survival rate.

Table 4. Feed utilization (mean \pm SD) after 12 weeks of feeding with control ( $0 \%$ BSFLM and 100\% FM), and FM replaced at $10 \%, 20 \%, 40 \%, 60 \%, 80 \%$, and $100 \%$ of the BSFLM.

\begin{tabular}{ccccccc}
\hline Diet & $\begin{array}{c}\text { Total Feed } \\
\text { Intake (kg) }\end{array}$ & $\begin{array}{c}\text { Rates of Feed } \\
\text { Intake } \\
\text { (g/fish/day) }\end{array}$ & $\begin{array}{c}\text { Feed } \\
\text { Conversion } \\
\text { Ratio }\end{array}$ & $\begin{array}{c}\text { Feed Efficiency } \\
\text { (\%) }\end{array}$ & $\begin{array}{c}\text { Total } \\
\text { Digestibility } \\
\text { (\%) }\end{array}$ & $\begin{array}{c}\text { Apparent } \\
\text { Protein } \\
\text { Digestibility } \\
\text { Coefficient (\%) }\end{array}$ \\
\hline 1 & $1.96 \pm 0.13$ & $1.25 \pm 0.08$ & $2.22 \pm 0.17$ & $45.08 \pm 3.32$ & $47.65 \pm 0.39$ & $75.22 \pm 0.52^{\mathrm{d}}$ \\
2 & $1.93 \pm 0.07$ & $1.24 \pm 0.05$ & $2.15 \pm 0.27$ & $46.92 \pm 5.39$ & $48.19 \pm 0.37$ & $76.20 \pm 0.16^{\mathrm{c}}$ \\
3 & $1.99 \pm 0.06$ & $1.28 \pm 0.04$ & $2.15 \pm 0.10$ & $46.63 \pm 2.03$ & $47.83 \pm 0.81$ & $76.17 \pm 0.30^{\mathrm{c}}$ \\
4 & $2.02 \pm 0.12$ & $1.29 \pm 0.08$ & $2.14 \pm 0.31$ & $47.38 \pm 6.39$ & $47.92 \pm 0.00$ & $77.45 \pm 0.23^{\mathrm{b}}$ \\
5 & $2.03 \pm 0.21$ & $1.30 \pm 0.13$ & $2.16 \pm 0.42$ & $47.25 \pm 8.31$ & $48.72 \pm 0.37$ & $78.04 \pm 0.27^{\mathrm{b}}$ \\
6 & $1.92 \pm 0.06$ & $1.23 \pm 0.04$ & $2.16 \pm 0.17$ & $46.53 \pm 3.83$ & $48.18 \pm 1.14$ & $77.38 \pm 0.45^{\mathrm{b}}$ \\
7 & $1.91 \pm 0.02$ & $1.23 \pm 0.01$ & $2.23 \pm 0.15$ & $44.92 \pm 2.90$ & $48.19 \pm 0.37$ & $82.84 \pm 0.60^{\mathrm{a}}$ \\
$p$-value & 0.757 & 0.758 & 0.998 & 0.993 & 0.687 & 0.000 \\
Means overall & $1.96 \pm 0.10$ & $1.26 \pm 0.07$ & $2.17 \pm 0.21$ & $46.39 \pm 4.31$ & $48.09 \pm 0.55$ & $77.61 \pm 2.41$ \\
\hline
\end{tabular}

$\mathrm{a}, \mathrm{b}-$ Different superscript letters indicate statistically different values.

The fish's morphometric indices show that no noticeable discrepancies in condition factor (CF), hepatosomatic (HSI), and viscerosomatic indexes (VSI) between the control and BSFLM substitution diets (Table 5). However, the final total length was significantly improved in fish fed Diet 3 (Table 5).

Table 5. Condition factor (CF), hepatosomatic index (HSI), and viscerosomatic index (VSI) after 12 weeks of feeding with control ( $0 \%$ BSFLM and 100\% FM), and FM replaced at 10\%, 20\%, 40\%, 60\%, 80\%, and 100\% of the BSFLM.

\begin{tabular}{cccccc}
\hline Diet & $\begin{array}{c}\text { Initial Total } \\
\text { Length } \mathbf{( c m )}\end{array}$ & $\begin{array}{c}\text { Final Total Length } \\
\mathbf{( \mathbf { c m } )}\end{array}$ & CF & HSI (\%) & VSI (\%) \\
\hline 1 & $9.73 \pm 0.80$ & $14.69 \pm 0.75^{\mathrm{b}}$ & $1.60 \pm 1.60$ & $1.67 \pm 0.34$ & $7.48 \pm 1.52$ \\
2 & $9.84 \pm 0.65$. & $15.30 \pm 0.59^{\mathrm{ab}}$ & $1.57 \pm 0.19$ & $1.63 \pm 0.43$ & $6.50 \pm 1.29$ \\
3 & $9.40 \pm 0.89$ & $15.55 \pm 0.72^{\mathrm{a}}$ & $1.60 \pm 0.06$ & $1.68 \pm 0.57$ & $6.33 \pm 1.15$ \\
4 & $9.71 \pm 1.03$ & $14.75 \pm 0.74^{\mathrm{b}}$ & $1.54 \pm 0.08$ & $1.39 \pm 0.30$ & $8.01 \pm 2.28$ \\
5 & $9.51 \pm 0.87$ & $15.17 \pm 0.88^{\mathrm{ab}}$ & $1.60 \pm 0.09$ & $1.62 \pm 0.38$ & $6.10 \pm 1.20$ \\
6 & $9.55 \pm 0.78$ & $14.69 \pm 0.52^{\mathrm{b}}$ & $1.61 \pm 0.10$ & $1.79 \pm 0.50$ & $7.23 \pm 1.74$ \\
7 & $9.70 \pm 0.60$ & $14.91 \pm 0.99^{\mathrm{b}}$ & $1.62 \pm 0.11$ & $1.69 \pm 0.48$ & $6.67 \pm 1.63$ \\
$p$-value & 0.785 & 0.011 & 0.576 & 0.330 & 0.137 \\
Means overall & $9.63 \pm 0.80$ & $15.01 \pm 0.80$ & $1.59 \pm 0.11$ & $1.64 \pm 0.44$ & $6.90 \pm 1.64$ \\
\hline
\end{tabular}


The optimum BSFLM was $47 \%$ based on quadratic regression of weight gain, final body weight, daily weight gain, specific growth rate, and relative growth rate. However, the linear regression showed no significant differences (Figures 1-6).

(a)

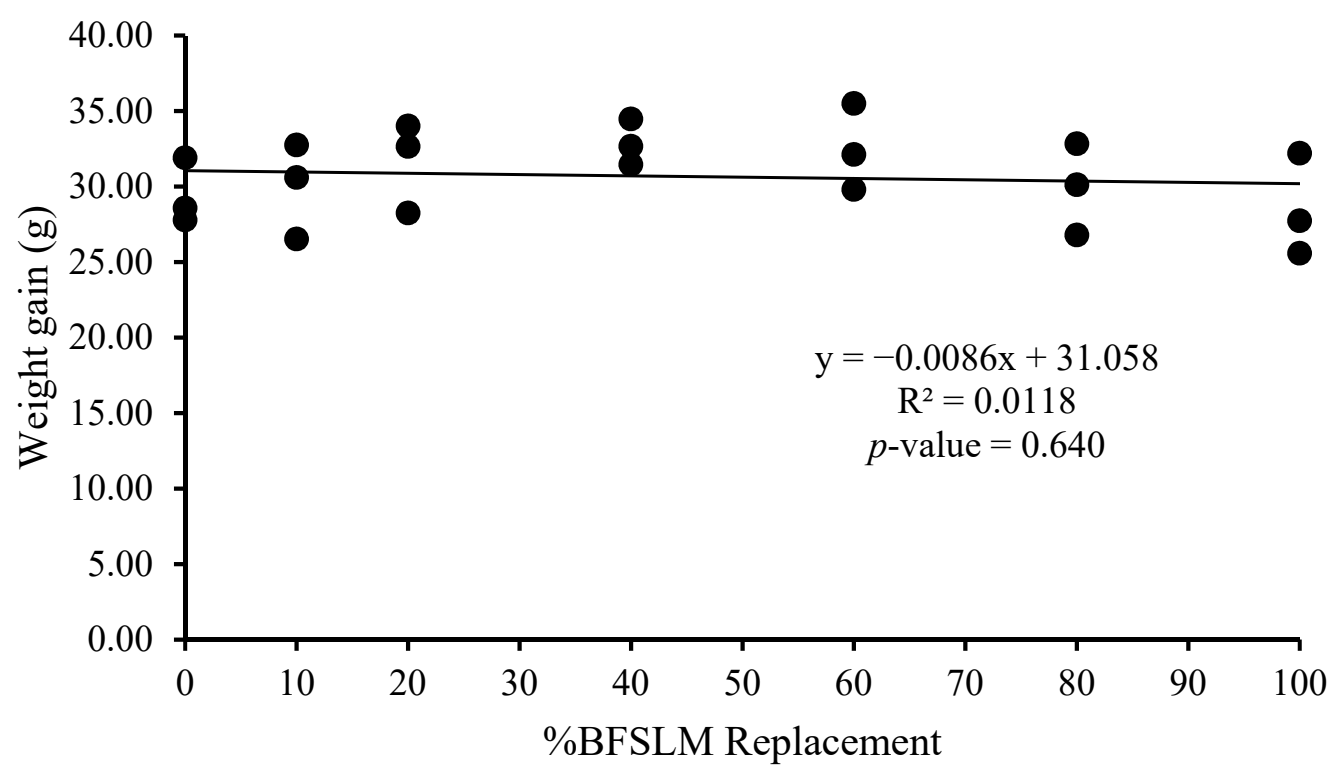

(b)

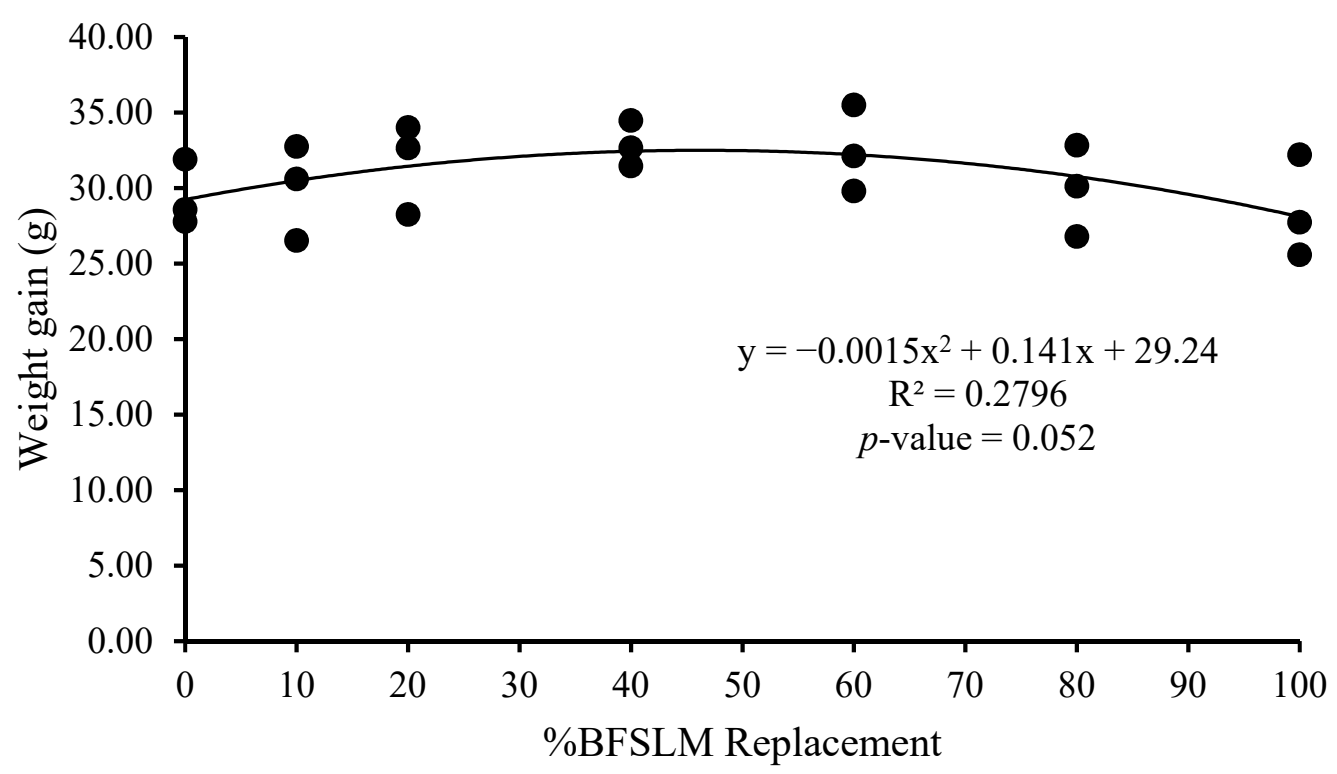

Figure 1. Linear (a) and quadratic (b) estimate: When $X=\%$ Black soldier fly larvae meal (BSFLM) replacement; $\mathrm{Y}=$ weight gained after 12 weeks of feeding with control ( $0 \%$ BSFLM and 100\% fish meal (FM)), and FM replaced at $10 \%, 20 \%, 40 \%, 60 \%, 80 \%$, and $100 \%$ of the BSFLM. 
(a)

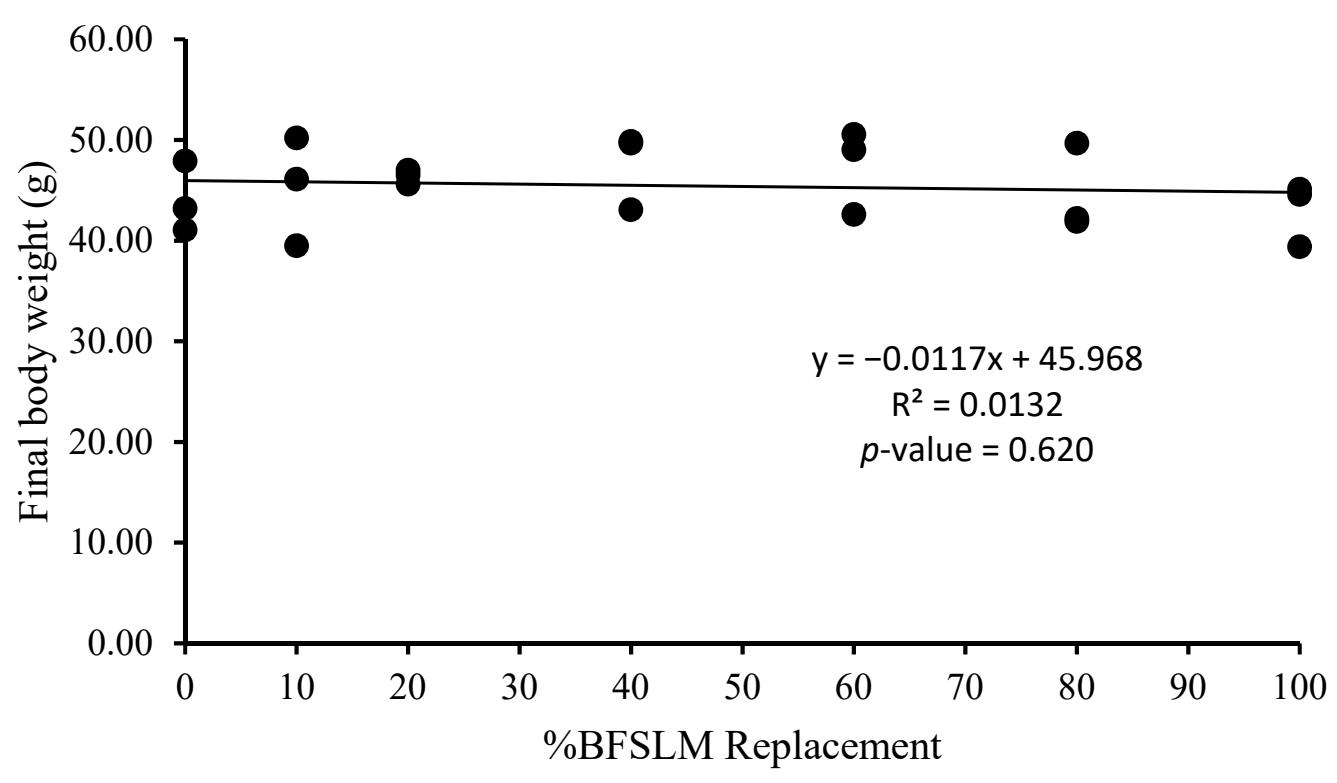

(b)

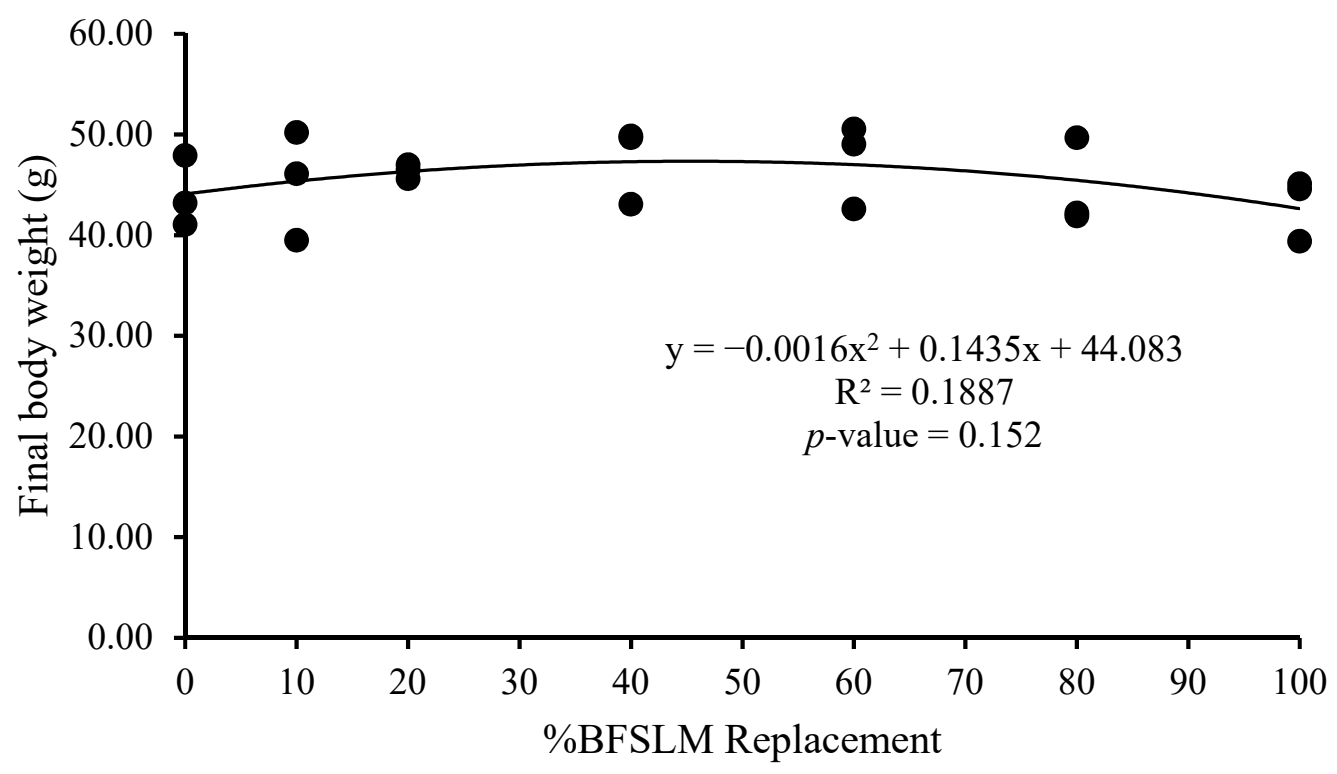

Figure 2. Linear (a) and quadratic (b) estimate: When $X=\% B S F L M$ replacement; $Y=$ Final body weight after 12 weeks of feeding with control ( $0 \%$ BSFLM and 100\% FM), and FM replaced at 10\%, $20 \%, 40 \%, 60 \%, 80 \%$, and $100 \%$ of the BSFLM. 
(a)

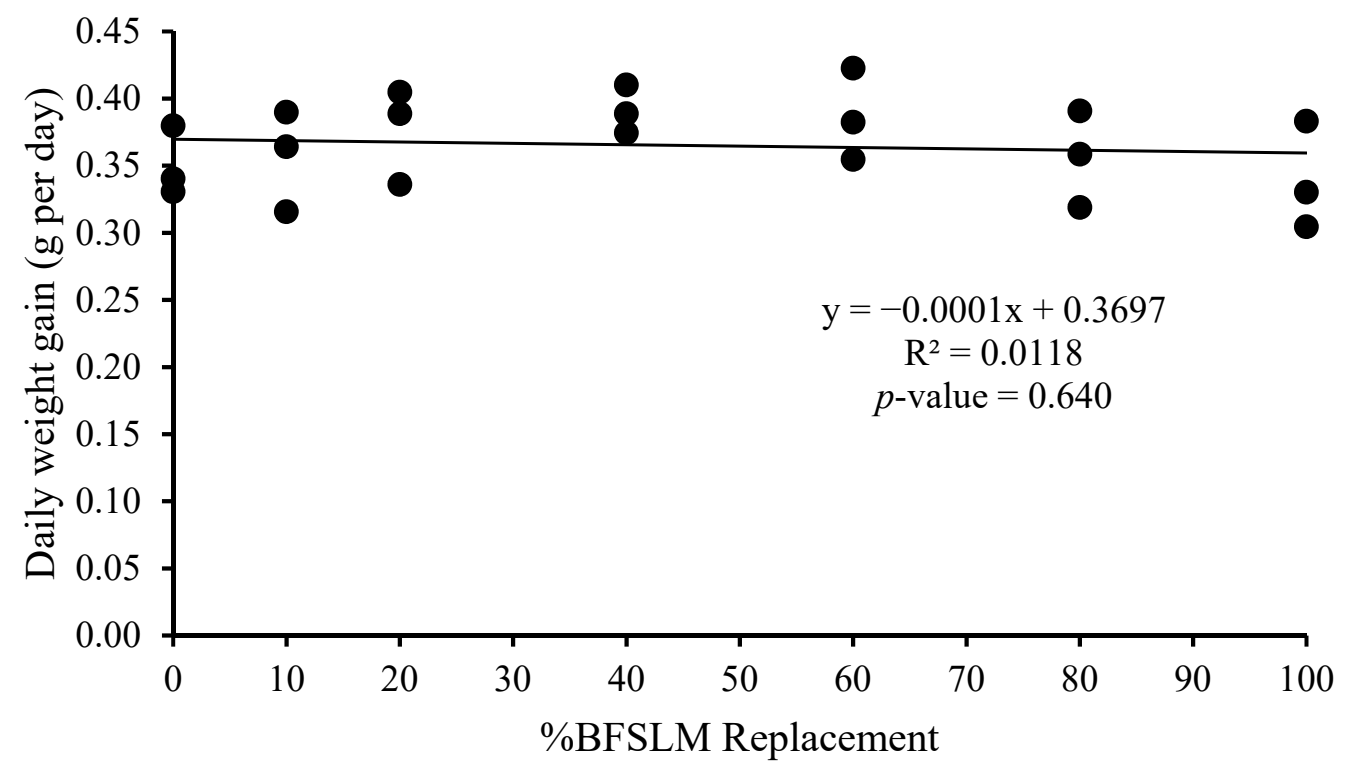

(b)

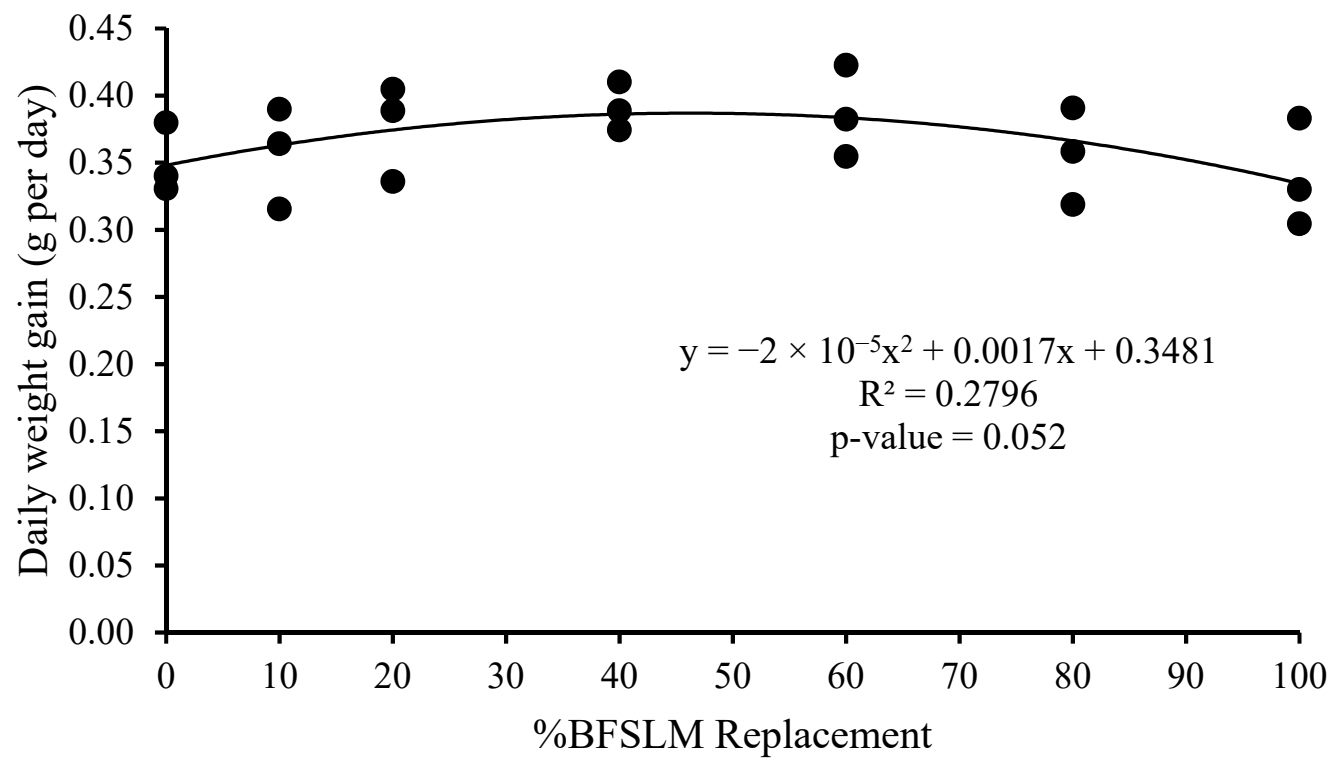

Figure 3. Linear (a) and quadratic (b) estimate: When $X=\% B S F L M$ replacement; $Y=$ Daily weight gain after 12 weeks of feeding with control (0\% BSFLM and 100\% FM), and FM replaced at 10\%, 20\%, $40 \%, 60 \%, 80 \%$, and $100 \%$ of the BSFLM. 
(a)

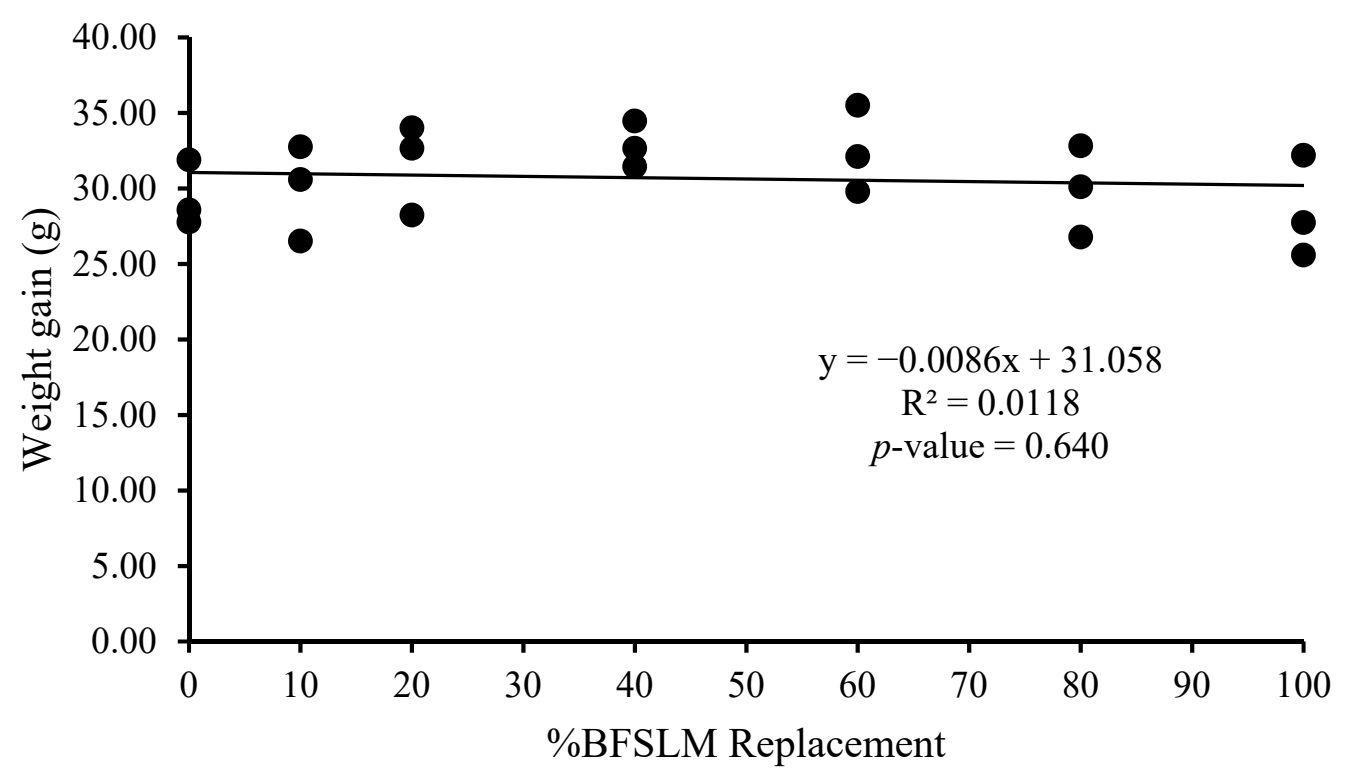

(b)

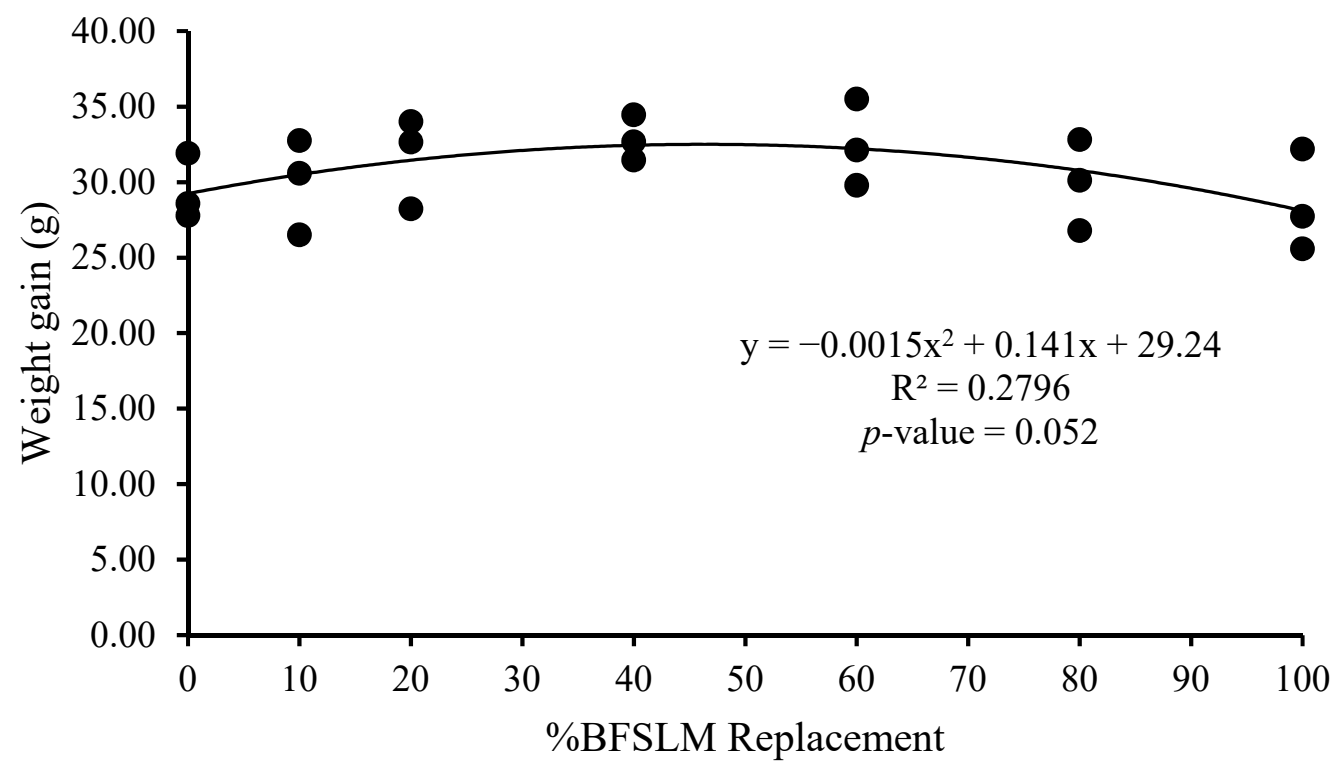

Figure 4. Linear (a) and quadratic (b) estimate: When $X=\% B S F L M$ replacement; $Y=$ Weight gain after 12 weeks of feeding with control ( $0 \%$ BSFLM and 100\% FM), and FM replaced at 10\%, 20\%, 40\%, $60 \%, 80 \%$, and $100 \%$ of the BSFLM. 
(a)

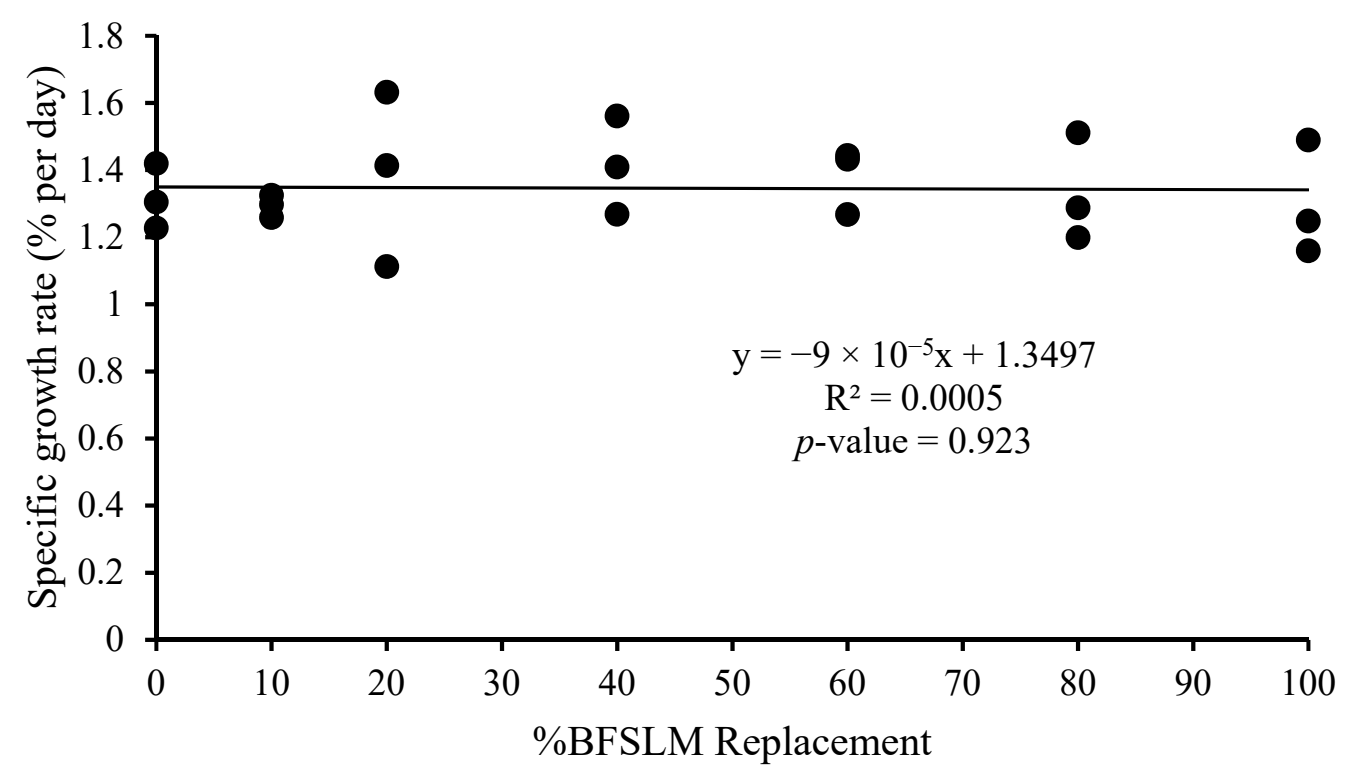

(b)

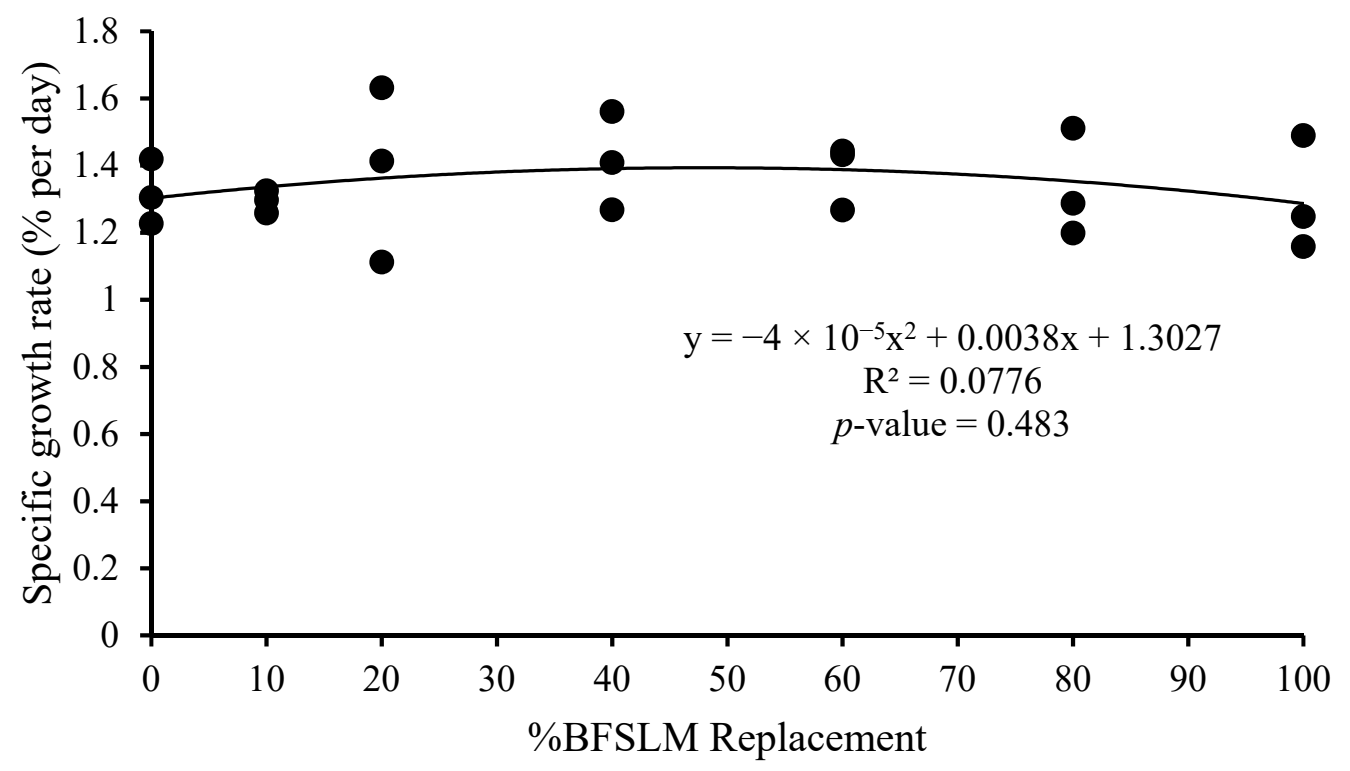

Figure 5. Linear (a) and quadratic (b) estimate: When $X=\% B S F L M$ replacement; $Y=$ Specific growth rate after 12 weeks of feeding with control ( $0 \%$ BSFLM and 100\% FM), and FM replaced at 10\%, 20\%, $40 \%, 60 \%, 80 \%$, and $100 \%$ of the BSFLM. 
(a)

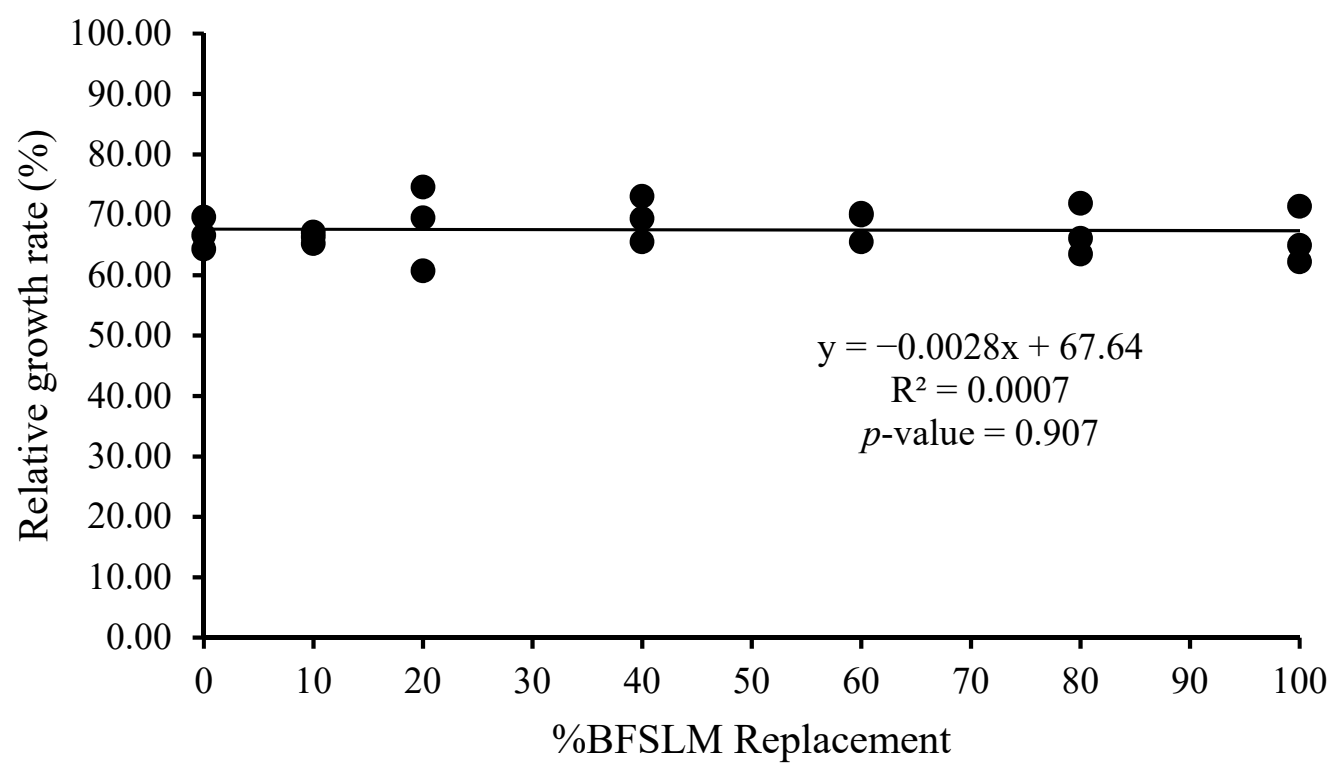

(b)

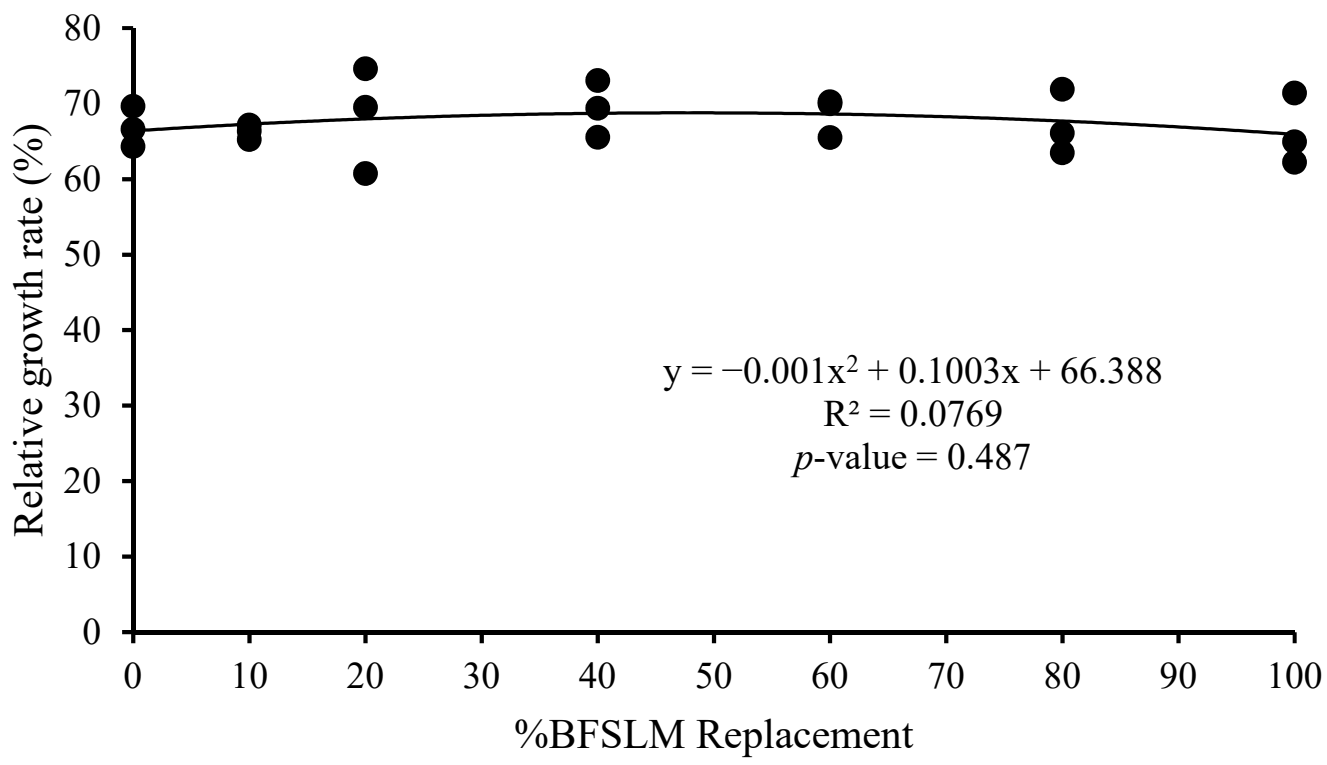

Figure 6. Linear (a) and quadratic (b) estimate: When $X=\% B S F L M$ replacement; $Y=$ Relative growth rate after 12 weeks of feeding with control ( $\%$ BSFLM and 100\% FM), and FM replaced at 10\%, 20\%, $40 \%, 60 \%, 80 \%$, and $100 \%$ of the BSFLM.

\subsection{Blood Parameters}

The blood parameters of Nile tilapia fed BSFLM are illustrated in Tables 6 and 7. The results reveal that there were no significant differences in Red blood cell (RBC), hemoglobin $(\mathrm{Hb})$, hematocrit $(\mathrm{HCT})$, mean corpuscular volume $(\mathrm{MCV})$, mean corpuscular hemoglobin $(\mathrm{MCH})$, mean corpuscular hemoglobin concentration $(\mathrm{MCHC})$, red blood cell distribution 
width (RDW-CV), and platelet (PLT). values between the control and BSFLM fed fish (Table 6).

Table 6. Blood parameters after 12 weeks of feeding with control ( $0 \%$ BSFLM and 100\% FM), and FM replaced at 10\%, 20\%, $40 \%, 60 \%, 80 \%$, and $100 \%$ of the BSF.

\begin{tabular}{|c|c|c|c|c|c|c|c|c|}
\hline Diet & $\begin{array}{c}\text { RBC } \\
10^{6} / \mu \mathrm{L}\end{array}$ & $\begin{array}{l}\mathrm{Hb} \\
\mathrm{g} / \mathrm{dL}\end{array}$ & $\begin{array}{c}\text { HCT } \\
\%\end{array}$ & $\begin{array}{c}\text { MCV } \\
\text { fl }\end{array}$ & $\begin{array}{c}\mathrm{MCH} \\
\text { pg }\end{array}$ & $\begin{array}{c}\text { MCHC } \\
\text { g/dL }\end{array}$ & $\begin{array}{c}\text { RDW-CV } \\
\%\end{array}$ & $\begin{array}{c}\text { PLT } \\
10^{3} / \mu \mathrm{L}\end{array}$ \\
\hline 1 & .33 & 37 & $23.24 \pm 6.33$ & $158.42 \pm 19.69$ & $35.36 \pm 3.22$ & $22.44 \pm 1.53$ & $12.41 \pm$ & $34.75 \pm 43.05$ \\
\hline 2 & $0.77 \pm$ & 3. & 12 & $159.40=$ & $48.82 \pm$ & 2 & & 4.18 \\
\hline 3 & $1.29 \pm 0.29$ & $4.89 \pm 1.29$ & $20.17 \pm 3$ & $157.94 \pm 18.11$ & $38.23 \pm 8.99$ & $24.00 \pm 3.10$ & $11.68 \pm 3.49$ & $17.00 \pm 12.73$ \\
\hline 4 & $1.23 \pm 0.43$ & $4.61 \pm 1.57$ & $20.03 \pm 7.05$ & $163.67 \pm 21.82$ & $37.95 \pm 5.71$ & $23.16 \pm 0.75$ & $14.30 \pm 4.26$ & $33.22 \pm 37.68$ \\
\hline 5 & $1.01 \pm 0.68$ & $4.11 \pm 1.92$ & $16.10 \pm 9.54$ & $167.81 \pm 19.46$ & $48.93 \pm 19.99$ & $28.56 \pm 8.95$ & $16.97 \pm$ & $25.64 \pm 25.49$ \\
\hline 6 & $1.24 \pm 0.63$ & $5.89 \pm 2.70$ & $22.40 \pm 12.86$ & $174.06 \pm 23.98$ & $48.01 \pm 11.76$ & $27.68 \pm 6.04$ & $15.01 \pm 2.96$ & $22.11 \pm 11.50$ \\
\hline 7 & $1.07 \pm 0.63$ & $4.34 \pm 2.58$ & $17.03 \pm 10.96$ & $157.64 \pm 20.84$ & $43.13 \pm 16.48$ & $27.04 \pm 8.23$ & $11.17 \pm 2.20$ & $34.75 \pm 34.34$ \\
\hline$p$-value & 0.340 & 0.547 & 0.378 & 0.639 & 0.236 & 0.171 & 1.69 & 0.85 \\
\hline $\begin{array}{l}\text { Means } \\
\text { overall }\end{array}$ & $1.18 \pm 0.52$ & $4.78 \pm 2.04$ & $19.28 \pm 9.09$ & $163.11 \pm 20.7$ & $42.65 \pm 13.52$ & $25.92 \pm 6.28$ & $13.20 \pm 3.88$ & $27.97 \pm 28.00$ \\
\hline
\end{tabular}

Red blood cell (RBC), hemoglobin ( $\mathrm{Hb})$, hematocrit (HCT), mean corpuscular volume (MCV), mean corpuscular hemoglobin (MCH), mean corpuscular hemoglobin concentration (MCHC), red blood cell distribution width (RDW-CV), Platelets (PLT). Also, no significant differences in white blood cell count (WBC), neutrophil, lymphocyte, and monocyte were detected between the control and BSFLM fed fish (Table 7).

Table 7. White blood cell count WBC differential after 12 weeks of feeding with control (0\% BSFLM and $100 \%$ FM), and FM replaced at $10 \%, 20 \%, 40 \%, 60 \%, 80 \%$, and $100 \%$ of the BSF.

\begin{tabular}{ccccc}
\hline Diet & $\begin{array}{c}\text { WBC } \\
\mathbf{1 0} / \boldsymbol{\mu L}\end{array}$ & $\begin{array}{c}\text { Neutrophil } \\
\mathbf{\%}\end{array}$ & $\begin{array}{c}\text { Lymphocyte } \\
\mathbf{\%}\end{array}$ & $\begin{array}{c}\text { Monocyte } \\
\mathbf{\%}\end{array}$ \\
\hline 1 & $3.59 \pm 1.36$ & $34.00 \pm 26.25$ & $50.78 \pm 26.88$ & $14.33 \pm 15.51$ \\
2 & $3.05 \pm 1.04$ & $47.40 \pm 24.94$ & $36.80 \pm 23.95$ & $13.80 \pm 5.45$ \\
3 & $3.58 \pm 1.01$ & $39.14 \pm 19.34$ & $47.00 \pm 21.49$ & $13.43 \pm 9.52$ \\
4 & $3.87 \pm 1.28$ & $24.90 \pm 13.64$ & $63.03 \pm 22.10$ & $11.09 \pm 12.49$ \\
5 & $4.25 \pm 0.96$ & $22.29 \pm 18.95$ & $63.00 \pm 17.26$ & $13.00 \pm 8.87$ \\
6 & $3.59 \pm 2.02$ & $47.22 \pm 33.32$ & $40.33 \pm 24.96$ & $11.33 \pm 10.91$ \\
7 & $3.69 \pm 0.92$ & $39.88 \pm 21.57$ & $45.25 \pm 28.93$ & $13.13 \pm 10.43$ \\
$p$-value & 0.838 & 0.261 & 0.260 & 0.996 \\
Means overall & $3.68 \pm 1.28$ & $35.95 \pm 23.97$ & $50.06 \pm 24.59$ & $12.77 \pm 10.72$ \\
\hline
\end{tabular}

\subsection{Skin Mucus Immune Response}

Skin mucus lysozyme (SMLA) and skin mucus peroxidase (SMPA) activities of fish fed BSFLM substitution diets are illustrated in Table 8. The results show that BSFLM diets significantly $(p \leq 0.05)$ stimulated SMLA and SMPA after 12 weeks of feeding with the maximum amounts recorded in Diet 4 and 5 compared to the control. No significant differences in SMLA and SMPA ( $p \geq 0.05$ ) were detected in fish fed diets 2, 3, 6, and 7 .

Table 8. Skin mucus lysozyme (SMLA) and skin mucus peroxidase (SMPA) after 12 weeks of feeding with control (0\% BSFLM and $100 \%$ FM), and FM replaced at $10 \%, 20 \%, 40 \%, 60 \%, 80 \%$, and $100 \%$ of the BSFLM.

\begin{tabular}{|c|c|c|c|c|c|c|c|}
\hline $\begin{array}{c}\text { Skin } \\
\text { Parameters }\end{array}$ & Diet 1 & Diet 2 & Diet 3 & Diet 4 & Diet 5 & Diet 6 & Diet 7 \\
\hline SMLA & $0.99 \pm 0.04^{c}$ & $1.45 \pm 0.05^{b}$ & $1.86 \pm 0.07^{b}$ & $2.59 \pm 0.12^{a}$ & $2.35 \pm 0.09^{a}$ & $1.55 \pm 0.21^{b}$ & $1.76 \pm 0.13^{b}$ \\
\hline SMPA & $0.09 \pm 0.006^{c}$ & $0.12 \pm 0.002^{b}$ & $0.13 \pm 0.007^{b}$ & $0.18 \pm 0.005^{\mathrm{a}}$ & $0.17 \pm 0.003^{a}$ & $0.12 \pm 0.002^{b}$ & $0.11 \pm 0.005^{b}$ \\
\hline
\end{tabular}




\section{Discussion}

Fish nutritionists focus on the feeding strategies required for the optimal growth of Nile tilapia in particular due to its popularity as an affordable, nutritious, and cheap source of animal proteins [38]. The use of black soldier fly larvae meal (BSFLM) as a potential source of protein in tilapia diets has been abundantly investigated $[7,22,24,39]$. Concurrently, the results of the present study illustrate that fish fed up to $100 \%$ of the BSFLM inclusion level (total replacement of fish meal (FM)) had no adverse effects on the growth performance, somatic indices, and survival rate of Nile tilapia. In this context, Rana, Salam, Hashem, and Islam [40] elucidated that mono-sex tilapia fed diets with BSFLM replaced with $50 \%$ of FM displayed similar growth performance to the control group. Similarly, Ushakova, Ponomarev, Bakaneva, Fedorovykh, Levina, Kotel'nikov, Kotel'nikova, Bastrakov, Kozlova, and Pavlov [41] reported that feeding Mozambique tilapia with dried flour of BSFLM pre-pupae in a dose of $0.5 \mathrm{~g} \mathrm{~kg}^{-1}$ of feed for 30 days resulted in a significant increase of average daily gain with no significant differences in the survival rate. Additionally, Dietz and Liebert [42] reported that the inclusion of $50 \%$ BSFLM as a replacer for soy protein-concentrate did not compromise the growth performance and feed conversion ratio (FCR) of Nile tilapia. Interestingly, when FM was replaced with $50 \%$ of BSFLM, the results displayed no adverse effects on the growth performance of Nile tilapia [43]. The replacement of $50 \%$ of the FM with a mixture of BSFLM and Manihot esculenta leaf meal resulted in increased growth of Nile tilapia [44]. Likewise, Devic, Leschen, Murray, and Little [45] observed no adverse effects on the growth performance of Nile tilapia fed up to $80 \mathrm{~g}$ BSF $/ \mathrm{kg}$ diet. Toriz-Roldan, Ruiz-Vega, GarcíaUlloa, Hernández-Llamas, Fonseca-Madrigal, and Rodríguez-González [46] illustrated that dietary inclusion of BSFLM at the rate of $6 \%$ did not affect the growth performance; however, the protein efficiency ratio was enhanced. More recently, Fisher, Collins, Hanson, Mason, Colombo, and Anderson [8] indicated that Atlantic salmon fed diets containing up $200 \mathrm{~g} \mathrm{~kg}^{-1}$ of BSFLM showed growth performances similar to the control. Similarly, no significant difference in the fish growth and survival rate was recorded in European sea bass (Dicentrarchus labrax) that was fed BSF at rates of up to 50\% [7]. Li, Kortner, Chikwati, Belghit, Lock, and Krogdahl [10] reported that total substitution of FM with BSFLM does not compromise the gut health of seawater phase Atlantic salmon.

The measured feed efficiency indices, such as total feed intake, rates of feed intake, feed conversion ratio, feed efficiency, and total digestibility were similar among tilapia groups that were fed different levels of BSFLM. These results were similar to previous results reported in rainbow trout (Oncorhynchus mykiss) [20,47], Atlantic salmon (S. salar) [8,10,48], Japanese seabass (Lateolabrax japonicas) [21], zebrafish (Danio rerio) [49], and European sea bass (D. labrax) [7,50]. Interestingly, a significantly higher apparent protein digestibility coefficient was observed in fish fed BSFLM compared to the control diets, and the highest value was observed in fish fed Diet 7 . The results were in disagreement with a previous study, which showed that the apparent digestibility coefficient of crude protein was lowest in fish fed insect meal diets [51]. The presence of chitin in insect meal might interfere with the utilization of protein $[52,53]$. Nonetheless, several investigations demonstrate that chitinolytic enzyme activities were found in the organs of some fish, such as gastric mucosa, intestinal mucosa, pyloric caeca, and pancreas [54-57]. Nile tilapia, an omnivorous species with a great ability to fed on plankton, may possess some advantages in chitin degradation and digestion $[53,58,59]$. The feeding nature and significant intake of chitin make it likely that chitinolytic enzymes play an important role for tilapia digestive physiology [53]. Moreover, the dietary inclusion of chitin could increase gut microflora diversity and act against several harmful bacteria, such as Escherichia coli, Anaerorhabdus furcosa, and Aeromonas hydropila [60-64]. Additionally, it has been reported that BSFLM is a rich source of omega 3,6, and $9[15,65-69]$, a composition that may improve the growth performance of the host. Based on quadratic regression analysis, the optimal BSFLM level was $47 \%$. However, it is important to underline that the lowest $p$-value for the quadratic analysis is $p=0.052$, slightly above the $p<0.05$ limit considered "significant". The optimal BSFLM level is higher 
than in Atlantic salmon (Salmo salar) (12.5\%) [39], hybrid tilapia (Nile $\times$ Mozambique, Oreocromis niloticus $\times$ O. mozambique) $(30 \%)$ [22], and rice field eel (Monopterus albus) $(15.78 \%)$ [24]; however, it is lower than in European sea bass (D. labrax) and grass carp (Ctenopharyngodon idellus) (50\%) [7,70] and Japanese seabass (L. japonicus) (64\%) [21].

Hematological indices of fish are regarded as essential measurements for evaluating the general health status and physiological stress responses of fish fed formulated rations [71]. Herein, the impacts of feeding BSFLM on several hematological indices of tilapia were evaluated. The results displayed that the inclusion of BSFLM did not influence the redblood cells (RBCs) or the white blood cells (WBCs). Also, Zhou, Liu, Ji, and Yu [72]

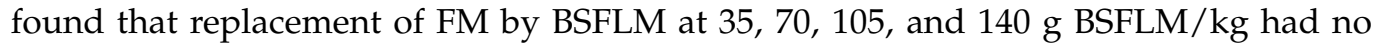
effects on Jian carp's glucose, total protein, albumin, globulin, aspartate transaminase and alanine transaminase. Yildirim-Aksoy, Eljack, Schrimsher, and Beck [22] also reported that hybrid tilapia (O. niloticus $\times$ O. mozambique) fed a 30\% BSFLM diet for 12 weeks showed no influence on hematological values values. Likewise, Abdel-Tawwab, Khalil, Metwally, Shakweer, Khallaf and Abdel-Latif [7], found that no significant changes were observed in counts of WBCs, lymphocytes, monocytes, and neutrophils in BSFLM-fed fish as compared to the FM-fed fish. Conversely, Ushakova, Ponomarev, Bakaneva, Fedorovykh, Levina, Kotel'nikov, Kotel'nikova, Bastrakov, Kozlova, and Pavlov [41] observed increased hemoglobin in Mozambique tilapia (O. mossambicus) fed on a diet supplemented with dried black soldier flypre-pupae flour for one month.

The lysozyme activity can act as a non-specific molecule that beneficially protects the fish from the infectious disease through the breakdown of 1,4 glycosidic bonds present in the peptidoglycan of both Gram-positive and Gram-negative cell walls [73]. The enhancement of serum lysozyme activity will help in the stimulation of the fish's immune responses and may contribute positively to the fish's resistance against the challenged pathogens $[24,74]$. The results displayed an improved lysozyme and peroxidase activities in the skin mucus of fish fed $4 \%$ and $6 \%$ BSFLM, which refers to the enhanced immunity of fish in these groups. Xiao, Jin, Zheng, Cai, Yu, Yu, and Zhang [75] illustrated that the serum lysozyme activity of yellow catfish was not significantly different between the groups fed with BSFLM when compared with the control group. However, their values were increased over the control fish. In addition, Foysal, Fotedar, Tay, and Gupta [23] illustrated that marron (Cherax cainii) fed on both BSFLM supplemented diets showed significant enhancement of serum lysozyme activity. It has been reported that several fish species are able to synthesize endogenous chitinases, probably due to differences in their gut microbiota [51]. It is well known that dietary BSFLM has abundant amounts of chitin involved in increasing the abundance of microbial communities in the fish gut, thus acting as prebiotic substances that could induce immunostimulant impacts on fish [76,77]. However, further studies are required to find out the reasons for the enhanced immunity of fish fed BSFLM.

\section{Conclusions}

It can be concluded that BSFLM is regarded as one of the best alternatives for partial or complete replacement of FM in Nile tilapia diets. Fish fed the optimal level of included BSFLM can grow ideally without any adverse effects on the feed efficiency, somatic indices, and hematological parameters. The optimal level of included BSFLM also increased activities of lysozyme and peroxidase in the skin mucus. Based on the obtained results, BSFLM can completely replace FM in the diets of Nile tilapia without compromising the growth performance, feed efficiency, and health condition.

Author Contributions: Conceptualization and methodology: H.V.D.; investigation: N.T.; writingoriginal draft preparation: M.A.O.D.; Writing—review and editing: H.V.D., S.H.H. and M.P.; Funding acquisition: H.V.D.; Resources: P.K. All authors have read and agreed to the published version of the manuscript.

Funding: This research was funded by the Chiang Mai University and Khon Kaen University. The open access fees were supported by the Fondi Ricerca di Ateneo (FRA), University of Sannio. 
Institutional Review Board Statement: The study was approved by Institutional Animal Care and Use Committee of Khon Kaen University, based on the Ethic of Animal Experimentation of National Research Council of Thailand.

Data Availability Statement: The data presented in this study are available on request from the corresponding author.

Conflicts of Interest: The authors declare no conflict of interest.

\section{References}

1. FAO. The State of World Fisheries and Aquaculture (SOFIA); FAO: Rome, Italy, 2020.

2. Guedes, A.C.; Sousa-Pinto, I.; Malcata, F.X. Chapter 8-Application of Microalgae Protein to Aquafeed. In Handbook of Marine Microalgae; Academic Press: Boston, MA, USA, 2015; pp. 93-125.

3. Cashion, T.; Le Manach, F.; Zeller, D.; Pauly, D. Most fish destined for fishmeal production are food-grade fish. Fish Fish. 2017, 18, 837-844. [CrossRef]

4. Turchini, G.M.; Trushenski, J.T.; Glencross, B.D. Thoughts for the Future of Aquaculture Nutrition: Realigning Perspectives to Reflect Contemporary Issues Related to Judicious Use of Marine Resources in Aquafeeds. N. Am. J. Aquac. 2018, 81, 13-39. [CrossRef]

5. Kobayashi, M.; Msangi, S.; Batka, M.; Vannuccini, S.; Dey, M.M.; Anderson, J.L. Fish to 2030: The Role and Opportunity for Aquaculture. Aquac. Econ. Manag. 2015, 19, 282-300. [CrossRef]

6. Konar, M.; Qiu, S.; Tougher, B.; Vause, J.; Tlusty, M.; Fitzsimmons, K.; Barrows, R.; Cao, L. Illustrating the hidden economic, social and ecological values of global forage fish resources. Resour. Conserv. Recycl. 2019, 151, 104456. [CrossRef]

7. Abdel-Tawwab, M.; Khalil, R.H.; Metwally, A.A.; Shakweer, M.S.; Khallaf, M.A.; Abdel-Latif, H.M. Effects of black soldier fly (Hermetia illucens L.) larvae meal on growth performance, organs-somatic indices, body composition, and hemato-biochemical variables of European sea bass, Dicentrarchus labrax. Aquaculture 2020, 522, 735136. [CrossRef]

8. Fisher, H.; Collins, S.A.; Hanson, C.; Mason, B.; Colombo, S.; Anderson, D. Black soldier fly larvae meal as a protein source in low fish meal diets for Atlantic salmon (Salmo salar). Aquaculture 2020, 521, 734978. [CrossRef]

9. Gasco, L.; Acuti, G.; Bani, P.; Zotte, A.D.; Danieli, P.P.; De Angelis, A.; Fortina, R.; Marino, R.; Parisi, G.; Piccolo, G.; et al. Insect and fish by-products as sustainable alternatives to conventional animal proteins in animal nutrition. Ital. J. Anim. Sci. 2020, 19, 360-372. [CrossRef]

10. Li, Y.; Kortner, T.M.; Chikwati, E.M.; Belghit, I.; Lock, E.-J. Krogdahl, Åshild Total replacement of fish meal with black soldier fly (Hermetia illucens) larvae meal does not compromise the gut health of Atlantic salmon (Salmo salar). Aquaculture 2020, 520, 734967. [CrossRef]

11. Arru, B.; Furesi, R.; Gasco, L.; Madau, F.; Pulina, P. The Introduction of Insect Meal into Fish Diet: The First Economic Analysis on European Sea Bass Farming. Sustainability 2019, 11, 1697. [CrossRef]

12. Hua, K.; Cobcroft, J.M.; Cole, A.; Condon, K.; Jerry, D.R.; Mangott, A.; Praeger, C.; Vucko, M.J.; Zeng, C.; Zenger, K.; et al. The Future of Aquatic Protein: Implications for Protein Sources in Aquaculture Diets. One Earth 2019, 1, 316-329. [CrossRef]

13. Basto, A.; Matos, E.; Valente, L.M. Nutritional value of different insect larvae meals as protein sources for European sea bass (Dicentrarchus labrax) juveniles. Aquaculture 2020, 521, 735085. [CrossRef]

14. Baiano, A. Edible insects: An overview on nutritional characteristics, safety, farming, production technologies, regulatory framework, and socio-economic and ethical implications. Trends Food Sci. Technol. 2020, 100, 35-50. [CrossRef]

15. Shumo, M.; Osuga, I.M.; Khamis, F.M.; Tanga, C.M.; Fiaboe, K.K.M.; Subramanian, S.; Ekesi, S.; Van Huis, A.; Borgemeister, C. The nutritive value of black soldier fly larvae reared on common organic waste streams in Kenya. Sci. Rep. 2019, 9, 1-13. [CrossRef]

16. Diener, S.; Zurbrügg, C.; Tockner, K. Conversion of organic material by black soldier fly larvae: Establishing optimal feeding rates. Waste Manag. Res. 2009, 27, 603-610. [CrossRef]

17. Nogales-Mérida, S.; Gobbi, P.; Józefiak, D.; Mazurkiewicz, J.; Dudek, K.; Rawski, M.; Kierończyk, B.; Józefiak, A. Insect meals in fish nutrition. Rev. Aquac. 2018, 11, 1080-1103. [CrossRef]

18. NRC. Nutrient Requirements of Fish and Shrimp; The national Academies Press: Washington, DC, USA, 2011.

19. Kouřimská, L.; Adámková, A. Nutritional and sensory quality of edible insects. NFS J. 2016, 4, 22-26. [CrossRef]

20. Dumas, A.; Raggi, T.; Barkhouse, J.; Lewis, E.; Weltzien, E. The oil fraction and partially defatted meal of black soldier fly larvae (Hermetia illucens) affect differently growth performance, feed efficiency, nutrient deposition, blood glucose and lipid digestibility of rainbow trout (Oncorhynchus mykiss). Aquaculture 2018, 492, 24-34. [CrossRef]

21. Wang, G.; Peng, K.; Hu, J.; Yi, C.; Chen, X.; Wu, H.; Huang, Y. Evaluation of defatted black soldier fly (Hermetia illucens L.) larvae meal as an alternative protein ingredient for juvenile Japanese seabass (Lateolabrax japonicus) diets. Aquaculture 2019, 507, 144-154. [CrossRef]

22. Yildirim-Aksoy, M.; Eljack, R.; Schrimsher, C.; Beck, B.H. Use of dietary frass from black soldier fly larvae, Hermetia illucens, in hybrid tilapia (Nile x Mozambique, Oreocromis niloticus x O. mozambique) diets improves growth and resistance to bacterial diseases. Aquac. Rep. 2020, 17, 100373. [CrossRef] 
23. Foysal, J.; Fotedar, R.; Tay, C.-Y.; Gupta, S.K. Dietary supplementation of black soldier fly (Hermetica illucens)meal modulates gut microbiota, innate immune response and health status of marron (Cherax cainii, Austin 2002) fed poultry-by-product and fishmeal based diets. PeerJ 2019, 7, e6891. [CrossRef]

24. Hu, Y.; Huang, Y.; Tang, T.; Zhong, L.; Chu, W.; Dai, Z.; Chen, K.; Hu, Y. Effect of partial black soldier fly (Hermetia illucens L.) larvae meal replacement of fish meal in practical diets on the growth, digestive enzyme and related gene expression for rice field eel (Monopterus albus). Aquac. Rep. 2020, 17, 100345. [CrossRef]

25. El Asely, A.; Amin, A.; El-Naby, A.S.A.; Samir, F.; El-Ashram, A.; Dawood, M.A. Ziziphus mauritiana supplementation of Nile tilapia (Oreochromis niloticus) diet for improvement of immune response to Aeromonas hydrophila infection. Fish Physiol. Biochem. 2020, 46, 1561-1575. [CrossRef]

26. El Asely, A.M.; Reda, R.M.; Salah, A.S.; Mahmoud, M.A.; Dawood, M.A. Overall performances of Nile tilapia (Oreochromis niloticus) associated with using vegetable oil sources under suboptimal temperature. Aquac. Nutr. 2020, 26, 1154-1163. [CrossRef]

27. Van Doan, H.; Hoseinifar, S.H.; Khanongnuch, C.; Kanpiengjai, A.; Unban, K.; Van Kim, V.; Srichaiyo, S. Host-associated probiotics boosted mucosal and serum immunity, disease resistance and growth performance of Nile tilapia (Oreochromis niloticus). Aquaculture 2018, 491, 94-100. [CrossRef]

28. AOAC. Official methods of analysis of AOAC International, 16th ed.; AOAC International: Arlington, MA, USA, $1995 ;$ Volume 1.

29. Standard Methods for the Examination of Water and Wastewater, 19th ed.; American Public Health Association: Washington, DC, USA, 1998.

30. Brown, B. Routine hematology procedures. Hematol. Princ. Proced. 1988, 198, 7-122.

31. Van Doan, h.; Lumsangkul, C.; Hoseinifar, S.H.; Hung, T.Q.; Stejskal, V.; Ringø, E.; Dawood, M.A.O.; Esteban, M.Á. Administration of watermelon rind powder to Nile tilapia (Oreochromis niloticus) culture under biofloc system: Effect on growth performance, innate immune response, and disease resistance. Aquaculture 2020, 528, 735574.

32. Halver, E.; Hardy, R.V. Fish Nutrition; Academic Press: San Diego, CA, USA, 2002.

33. Lim, H.-A.; Ng, W.-K.; Lim, S.-L.; Ibrahim, C.O. Contamination of palm kernel meal with Aspergillus flavus affects its nutritive value in pelleted feed for tilapia, Oreochromis mossambicus. Aquac. Res. 2001, 32, 895-905. [CrossRef]

34. Parry, R.M.; Chandan, R.C.; Shahani, K.M. A Rapid and Sensitive Assay of Muramidase. In Proceedings of the Experimental Biology and Medicine; Society for Experimental Biology and Medicine, New York, NY, USA, 1 June 1965; Volume 119, pp. 384-386.

35. Van Doan, H.; Hoseinifar, S.H.; Jaturasitha, S.; Dawood, M.A.; Harikrishnan, R. The effects of berberine powder supplementation on growth performance, skin mucus immune response, serum immunity, and disease resistance of Nile tilapia (Oreochromis niloticus) fingerlings. Aquaculture 2020, 520, 734927. [CrossRef]

36. Cordero, H.; Cuesta, A.; Meseguer, J.; Esteban, M.A. Changes in the levels of humoral immune activities after storage of gilthead seabream ( Sparus aurata ) skin mucus. Fish Shellfish. Immunol. 2016, 58, 500-507. [CrossRef]

37. Yossa, R.; Verdegem, M.C.J. Misuse of multiple comparison tests and underuse of contrast procedures in aquaculture publications. Aquaculture 2015, 437, 344-350. [CrossRef]

38. Dawood, M.A.; Amer, A.A.; ElBialy, Z.I.; Gouda, A.H. Effects of including triticale on growth performance, digestive enzyme activity, and growth-related genes of Nile tilapia (Oreochromis niloticus). Aquaculture 2020, 528, 735568. [CrossRef]

39. Weththasinghe, P.; Hansen, J.; Nøkland, D.; Lagos, L.; Rawski, M.; Øverland, M. Full-fat black soldier fly larvae (Hermetia illucens) meal and paste in extruded diets for Atlantic salmon (Salmo salar): Effect on physical pellet quality, nutrient digestibility, nutrient utilization and growth performances. Aquaculture 2021, 530, 735785. [CrossRef]

40. Rana, K.S.; Salam, M.; Hashem, S.; Islam, M.A. Development of black soldier fly larvae production technique as an alternate fish feed. Int. J. Res. Fish. Aquac. 2015, 5, 41-47.

41. Ushakova, N.A.; Ponomarev, S.V.; Bakaneva, Y.M.; Fedorovykh, Y.V.; Levina, O.A.; Kotel’Nikov, A.V.; Kotel'Nikova, S.V.; Bastrakov, A.I.; Kozlova, A.A.; Pavlov, D.S. Biological Efficiency of the Prepupae Hermetia illucens in the Diet of the Young Mozambique Tilapia Oreochromis mossambicus. Biol. Bull. 2018, 45, 382-387. [CrossRef]

42. Dietz, C.; Liebert, F. Does graded substitution of soy protein concentrate by an insect meal respond on growth and N-utilization in Nile tilapia (Oreochromis niloticus)? Aquac. Rep. 2018, 12, 43-48. [CrossRef]

43. Muin, H.; Taufek, N.; Kamarudin, M.; Razak, S. Growth performance, feed utilization and body composition of Nile tilapia, Oreochromis niloticus (Linnaeus, 1758) fed with different levels of black soldier fly, Hermetia illucens (Linnaeus, 1758) maggot meal diet. Iran. J. Fish. Sci. 2017, 16, 567-577.

44. Aini, N.; Nugroho, R.A.; Hariani, N. Growth and Survival Evaluation of Oreochromis Sp fed Hermetia illucens Larva and Manihot esculenta leaves Meal. Biosaintifika J. Biol. Biol. Educ. 2018, 10, 565-573. [CrossRef]

45. Devic, E.; Leschen, W.; Murray, F.; Little, D.C. Growth performance, feed utilization and body composition of advanced nursing Nile tilapia (Oreochromis niloticus) fed diets containing Black Soldier Fly (Hermetia illucens) larvae meal. Aquac. Nutr. 2017, 24, 416-423. [CrossRef]

46. Toriz-Roldan, A.; Ruiz-Vega, J.; García-Ulloa, M.; Hernández-Llamas, A.; Fonseca-Madrigal, J.; Rodríguez-González, H. Assessment of Dietary Supplementation Levels of Black Soldier Fly, Hemertia illucens1, Pre-Pupae Meal for Juvenile Nile Tilapia, Oreochromis niloticus. Southwest. Entomol. 2019, 44, 251-259.

47. Renna, M.; Schiavone, A.; Gai, F.; Dabbou, S.; Lussiana, C.; Malfatto, V.; Prearo, M.; Capucchio, M.T.; Biasato, I.; Biasibetti, E.; et al. Evaluation of the suitability of a partially defatted black soldier fly (Hermetia illucens L.) larvae meal as ingredient for rainbow trout (Oncorhynchus mykiss Walbaum) diets. J. Anim. Sci. Biotechnol. 2017, 8, 57. [CrossRef] 
48. Belghit, I.; Liland, N.S.; Gjesdal, P.; Biancarosa, I.; Menchetti, E.; Li, Y.; Waagbø, R.; Krogdahl, Å.; Lock, E.-J. Black soldier fly larvae meal can replace fish meal in diets of sea-water phase Atlantic salmon (Salmo salar). Aquaculture 2019, 503, 609-619. [CrossRef]

49. Zarantoniello, M.; Randazzo, B.; Truzzi, C.; Giorgini, E.; Marcellucci, C.; Vargas-Abúndez, J.A.; Zimbelli, A.; Annibaldi, A.; Parisi, G.; Tulli, F.; et al. A six-months study on Black Soldier Fly (Hermetia illucens) based diets in zebrafish. Sci. Rep. 2019, 9, 8598. [CrossRef]

50. Magalhães, R.; Sánchez-López, A.; Leal, R.S.; Martínez-Llorens, S.; Oliva-Teles, A.; Peres, H. Black soldier fly (Hermetia illucens) pre-pupae meal as a fish meal replacement in diets for European seabass (Dicentrarchus labrax). Aquaculture 2017, 476, 79-85.

51. Caimi, C.; Renna, M.; Lussiana, C.; Bonaldo, A.; Gariglio, M.; Meneguz, M.; Dabbou, S.; Schiavone, A.; Gai, F.; Elia, A.C.; et al. First insights on Black Soldier Fly (Hermetia illucens L.) larvae meal dietary administration in Siberian sturgeon (Acipenser baerii Brandt) juveniles. Aquaculture 2020, 515, 734539. [CrossRef]

52. Belforti, M.; Gai, F.; Lussiana, C.; Renna, M.; Malfatto, V.; Rotolo, L.; De Marco, M.; Dabbou, S.; Schiavone, A.; Zoccarato, I.; et al. Tenebrio molitor meal in rainbow trout (Oncorhynchus mykiss) diets: Effects on animal performance, nutrient digestibility and chemical composition of fillets. Ital. J. Anim. Sci. 2015, 14, 4170. [CrossRef]

53. Fontes, T.V.; Oliveira, K.R.B.; Almeida, I.L.G.; Orlando, T.M.M.; Rodrigues, P.B.; Da Costa, D.V.; Rosa, P.V.E. Digestibility of Insect Meals for Nile Tilapia Fingerlings. Animals 2019, 9, 181. [CrossRef]

54. Jeuniaux, C. Chitinolytic systems in the digestive tract of vertebrates: A review. Chitin Enzymol. 1993, 1, $233-244$.

55. Ikeda, M.; Shirase, D.; Sato, T.; Ueda, M.; Hirabayashi, S.; Matsumiya, M. Primary Structure and Enzymatic Properties of Chitinase Isozymes Purified from the Stomach of the Marbled Rockfish Sebastiscus marmoratus. J. Chitin Chitosan Sci. 2014, 2, 106-116. [CrossRef]

56. Ikeda, M.; Miyauchi, K.; Matsumiya, M. Purification and Characterization of a $56 \mathrm{kDa}$ Chitinase Isozyme (PaChiB) from the Stomach of the Silver Croaker,Pennahia argentatus. Biosci. Biotechnol. Biochem. 2012, 76, 971-979. [CrossRef]

57. Krogdahl, A.; Hemre, G.-I.; Mommsen, T. Carbohydrates in fish nutrition: Digestion and absorption in postlarval stages. Aquac. Nutr. 2005, 11, 103-122. [CrossRef]

58. Cottrell, M.T.; Moore, J.A.; Kirchman, D.L. Chitinases from Uncultured Marine Microorganisms. Appl. Environ. Microbiol. 1999, 65, 2553-2557. [CrossRef]

59. Abdel-Ghany, H.M.; Salem, M.E. Effects of dietary chitosan supplementation on farmed fish; a review. Rev. Aquac. 2019, 12, 438-452. [CrossRef]

60. Nawaz, A.; Javaid, A.B.; Irshad, S.; Hoseinifar, S.H.; Xiong, H. The functionality of prebiotics as immunostimulant: Evidences from trials on terrestrial and aquatic animals. Fish Shellfish. Immunol. 2018, 76, 272-278. [CrossRef]

61. Zhou, Z.; Karlsen, Ø.; He, S.; Olsen, R.E.; Yao, B.; Ringø, E. The effect of dietary chitin on the autochthonous gut bacteria of Atlantic cod (Gadus morhua L.). Aquac. Res. 2013, 44, 1889-1900.

62. Qin, C.; Zhang, Y.; Liu, W.; Xu, L.; Yang, Y.; Zhou, Z. Effects of chito-oligosaccharides supplementation on growth performance, intestinal cytokine expression, autochthonous gut bacteria and disease resistance in hybrid tilapia Oreochromis niloticus o $\times$ Oreochromis aureus $\sigma^{7}$. Fish Shellfish. Immunol. 2014, 40, 267-274. [CrossRef]

63. Rimoldi, S.; Gini, E.; Iannini, F.; Gasco, L.; Terova, G. The Effects of Dietary Insect Meal from Hermetia illucens Prepupae on Autochthonous Gut Microbiota of Rainbow Trout (Oncorhynchus mykiss). Animals 2019, 9, 143. [CrossRef]

64. Kamilya, D.; Khan, M.I.R. Chapter 24-Chitin and chitosan as promising immunostimulant for aquaculture. In Handbook of Chitin and Chitosan; Elsevier: New York, NY, USA, 2020; pp. 761-771.

65. Oonincx, D.G.A.B.; Van Broekhoven, S.; Van Huis, A.; Van Loon, J.J.A. Feed Conversion, Survival and Development, and Composition of Four Insect Species on Diets Composed of Food By-Products. PLoS ONE 2015, 10, e0144601. [CrossRef]

66. Barragan-Fonseca, K.; Dicke, M.; Van Loon, J. Nutritional value of the black soldier fly (Hermetia illucens L.) and its suitability as animal feed-A review. J. Insects Food Feed. 2017, 3, 105-120. [CrossRef]

67. Ewald, N.; Vidakovic, A.; Langeland, M.; Kiessling, A.; Sampels, S.; Lalander, C. Fatty acid composition of black soldier fly larvae (Hermetia illucens)_Possibilities and limitations for modification through diet. Waste Manag. 2020, 102, 40-47. [CrossRef]

68. Erbland, P.; Alyokhin, A.; Perkins, L.B.; Peterson, M. Dose-Dependent Retention of Omega-3 Fatty Acids by Black Soldier Fly Larvae (Diptera: Stratiomyidae). J. Econ. Ėntomol. 2020, 113, 1221-1226. [CrossRef]

69. Liland, N.S.; Biancarosa, I.; Araujo, P.; Biemans, D.; Bruckner, C.G.; Waagbø, R.; Torstensen, B.E.; Lock, E.-J. Modulation of nutrient composition of black soldier fly (Hermetia illucens) larvae by feeding seaweed-enriched media. PLoS ONE 2017, 12, e0183188. [CrossRef]

70. Lu, R.; Chen, Y.; Yu, W.; Lin, M.; Yang, G.; Qin, C.; Meng, X.; Zhang, Y.; Ji, H.; Nie, G. Defatted black soldier fly (Hermetia illucens) larvae meal can replace soybean meal in juvenile grass carp (Ctenopharyngodon idellus) diets. Aquac. Rep. 2020, 18, 100520. [CrossRef]

71. Dawood, M.A.; Eweedah, N.M.; Khalafalla, M.M.; Khalid, A. Evaluation of fermented date palm seed meal with Aspergillus oryzae on the growth, digestion capacity and immune response of Nile tilapia (Oreochromis niloticus). Aquac. Nutr. 2020, 26, 828-841. [CrossRef]

72. Zhou, J.; Liu, S.; Ji, H.; Yu, H. Effect of replacing dietary fish meal with black soldier fly larvae meal on growth and fatty acid composition of Jian carp (Cyprinus carpio var. Jian). Aquac. Nutr. 2018, 24, 424-433. [CrossRef]

73. Yano, T. The Nonspecific Immune System: Humoral Defense. In The Fish Immune System: Organism, Pathogen and Environment; Iwama, G., Nakanishi, T., Eds.; Academic Press: San Diego, CA, USA, 1996; pp. 105-157. 
74. Van Doan, H.; Hoseinifar, S.H.; Hung, T.Q.; Lumsangkul, C.; Jaturasitha, S.; El-Haroun, E.; Paolucci, M. Dietary inclusion of chestnut (Castanea sativa) polyphenols to Nile tilapia reared in biofloc technology: Impacts on growth, immunity, and disease resistance against Streptococcus agalactiae. Fish Shellfish. Immunol. 2020, 105, 319-326. [CrossRef]

75. Xiao, X.; Jin, P.; Zheng, L.; Cai, M.; Yu, Z.; Yu, J.; Zhang, J. Effects of black soldier fly (Hermetia illucens) larvae meal protein as a fishmeal replacement on the growth and immune index of yellow catfish (Pelteobagrus fulvidraco). Aquac. Res. 2018, 49, 1569-1577. [CrossRef]

76. Bruni, L.; Pastorelli, R.; Viti, C.; Gasco, L.; Parisi, G. Characterisation of the intestinal microbial communities of rainbow trout (Oncorhynchus mykiss) fed with Hermetia illucens (black soldier fly) partially defatted larva meal as partial dietary protein source. Aquaculture 2018, 487, 56-63. [CrossRef]

77. Terova, G.; Rimoldi, S.; Ascione, C.; Gini, E.; Ceccotti, C.; Gasco, L. Rainbow trout (Oncorhynchus mykiss) gut microbiota is modulated by insect meal from Hermetia illucens prepupae in the diet. Rev. Fish Biol. Fish. 2019, 29, 465-486. [CrossRef] 